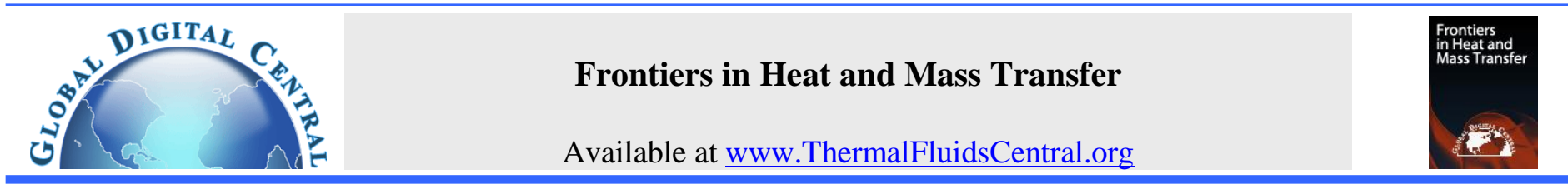

\title{
A REVIEW ON EXERGY ANALYSIS OF NANOFLUID FLOW THROUGH SEVERAL CONDUITS
}

\author{
Lohit Sharma ${ }^{\mathrm{a}}$, Sunil Kumar ${ }^{\mathrm{a}}$, Robin Thakura, Bhaskar Goela, Amar Raj Singh Suri ${ }^{\mathrm{a}}$, Sashank Thapa ${ }^{\mathrm{a}}$, Nitin Kumara, \\ Rajesh Maithani ${ }^{\text {, }}$ Anil Kumar ${ }^{\mathrm{b}}$, \\ ${ }^{a}$ School of Mechanical and Civil Engineering, Shoolini University, 173212, Solan, Himachal Pradesh, India \\ ${ }^{b}$ Department of Mechanical Engineering, University of Petroleum and Energy Studies, 248001, Dehradun, Uttarakhand, India
}

\begin{abstract}
This article presents an extensive review on exergy analysis of nanofluid flow through heat exchanger channels. The improvement of exergy efficiency of nanofluid flow through heat exchanger are determined by the net impact of the relative variations in the thermophysical properties of the nanoparticle which are sensitive towards numerous parameters including size and shape, material and concentration as well as base fluid thermal properties. Exergy efficiency of nanofluids flowing through heat exchanger is greater as compare to simple conventional fluids. The augmentation of exergy efficiency in the nanofluid flow through heat exchangers can be achieved by breaking laminar sub layer near the heating surface and can be efficiently done by employing obstacle as roughness elements. However, this gain is accomplished at the expense of decrease in pressure drop. Also exergy efficiency found to be augmented with the rise of the volume fraction with reduction in the value of nanoparticle diameter.
\end{abstract}

Keywords: Exergy analysis, heat exchanger, nanofluid, heat transfer.

\section{INTRODUCTION}

Exergy is defined as the maximum theoretical useful work obtained if a system is brought into thermodynamic equilibrium with the environment by means of processes in which the system interacts only with this environment (Enrico 2007). Such a final state of equilibrium is known as dead state. From another point of view, the exergy can be considered as a measure of the existing disequilibrium between the considered matter and the environment (Querol, et al. 2013). At the dead state, the combined system possesses energy but no exergy (Moran 1994), (McGovern 1990).

The critical role of the exergy analysis in the several engineering systems and processes including fuel cells, latent heat thermal energy storage, heat exchangers and thermal desalination of energy systems as well as identification of their actual and theoretical limits of performance were recognized by different researchers (Singh, et al. 2018) (Shabgard and Faghri 2019). Various researcher has provided the key insights on how the available energy (exergy) is being destroyed during the process and the ways to minimize its destruction through entropy generation minimization approach (Dutta and Biswas 2018), (Jedsadaratanachai and Boonloia 2018).

Nanofluids have the potential to enhance the thermal performance of high heat flux devices, such as in a nuclear reactor. The application of nanofluid can greatly improve the critical heat flux of the coolant so that there is a bottom-line economic benefit while also raising the safety standard of the power plant system. The safety system around the core of the reactor will include nanofluids to increase or decrease heat exchange efficiency through the control system is added to the control: the size, quantity and type of nanoparticles in the heat exchanger (Ahmed, Baig et al. 2019).
Two remarkable properties of nanofluids utilized are, one is the thermo-physical properties of nanofluids, enhancing the heat transfer and another is the application of nanofluids in solar collectors. (Nagarajan, Subramani et al. 2014). The idea behind using nanoparticle within the base (host) fluid is to increase the thermal conductivity of the carrying fluid, which leads to boosting the heat transfer phenomenon through the system. Use of conventional fluids like air and water in $\mathrm{PV} / \mathrm{T}$ systems limits the amount of heat that can be transferred from the panel. Researchers have tried to eliminate this shortcoming by using nanofluids as a heat transfer carrier with higher thermal conductivities (Ahmad et al. 2020).

\subsection{Basic points of exergy}

Exergy of a thermodynamic system is the maximum theoretical useful work (shaft work or electrical work) obtainable as the system is brought into complete thermodynamic equilibrium with the thermodynamic environment while the system interacts with this environment only (Tsatsaronis 2007). The concept of exergy is based on the second law of thermodynamics and in practice relies heavily on the use of the thermodynamic property entropy (McGovern 1990). The word exergy was first coined by to determine the fractional portion of heat energy which can be converted into effective work under ideal conditions by the heat source under existing environment conditions. By using the exergy concept, the available quantity of the heat collected can readily be determined by taking into account both the quantity (heat quantity) and the quality (a function of temperature) of the thermal energy (Suzuki 1987).

Exergy is a property of two states, the state of the system and the state of the environment. Its magnitude can be looked upon as a measure of the departure of the state of the system from that of the environment (Kotas 1980). Exergy is not generally conserved but is destroyed. A limiting case is when exergy would be completely 
destroyed, as would occur if a system were to come into equilibrium with the environment spontaneously with no provision to obtain work (Moran 1994). The exergy concept is mostly used within energy engineering, where you work with energy of varying qualities. However, the field of application can be extended to the totality of energy and material conversions in the society. This yields a uniform description of the use of physical resources and environmental impacts in connection with this use (Wall 1990), (Dincer 2001), (Dincer 2010), (McGovern 1990).

\section{PREVIOUS INVESTIGATIONS ON EXERGY ANALYSIS WITH NANOFLUIDS}

Nanofluids are the most recent approach in more than a century of work to improve the thermal conductivity of liquids. The low thermal conductivity of conventional heat transfer fluids HTFs is a serious limitation in improving the performance and compactness of engineering equipment (Das et al. 2006).

Specifically, nanofluids are a novel class of nanotechnologybased heat transfer fluids that are engineered by stably suspending a small amount 1 vol $\%$ or less of particles, or tubes with lengths on the order of 1-50 nm in traditional HTFs. The concept and the term were proposed by Choi in the early 1990. Common heat transfer fluids such as water, ethylene glycol, and engine oil have limited heat transfer capabilities due to their low heat transfer properties (Li et al. 2018) and (Yimin 2000).

Cooling is one of the most important technical challenges facing many diverse industries, including microelectronics, transportation, solid state lighting, and manufacturing. There is, therefore, an urgent need for new and innovative coolants with improved performance (Manca et al. 2015).

\subsection{Exergy analysis of $\mathrm{Al}_{2} \mathrm{O}_{3}$ based nanofluid flow through conduits}

Chen and Ding (2011) examined the problem of forced convection heat transfer in a microchannel heat sink with pure water and water-based nanofluids containing $\gamma^{-} \mathrm{Al}_{2} \mathrm{O}_{3}$ nanoparticles by modelling the microchannel as a fluid-saturated porous medium. They discussed effects of the inertial force term on the heat transfer behaviour and the MCHS performance are examined. Fig. 1 represents the schematic of the microchannel heat sink. The temperature distribution of the channel wall is found to be practically insensitive to the inertial effect, while the fluid temperature distribution and the total thermal resistance alter noticeably due to the inclusion of flow inertial force (Chen and Ding 2011).

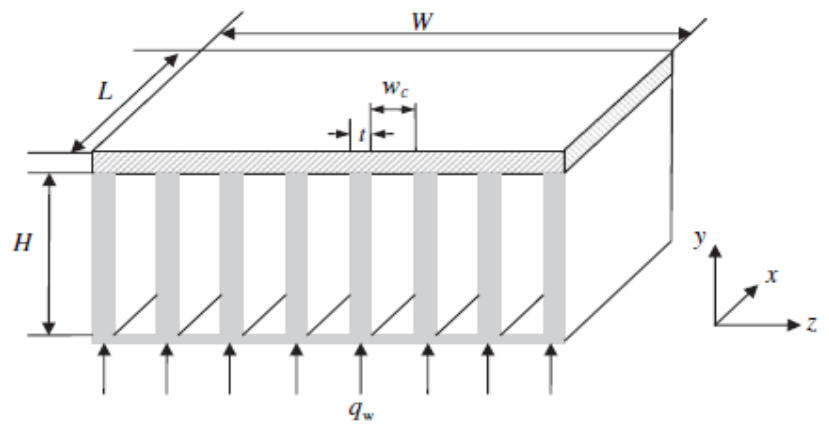

Fig. 1 Schematic of the microchannel heat sink(Chen and Ding 2011)

Hung et al. (2012) investigate mathematical model based on the first law and second law of thermodynamics of water-alumina nanofluids in circular microchannels during steady state. They observed that the rise of entropy generation induced by the rise of nanoparticle volume fraction is attributed to the rise of both the thermal conductivity and viscosity of nanofluid which causes augmentation in the heat transfer and fluid friction irreversibility, respectively. Manca, Nardini et al. (2012) carried out 2-D ribbed channel with square and rectangular ribs, mounted on the principal walls and heated by a uniform heat flux. The fluid was a mixture of water and $\mathrm{Al}_{2} \mathrm{O}_{3}$ nanoparticles. They observed that the highest $\mathrm{Nu}$ values were evaluated for $\mathrm{P} / \mathrm{e}=8$ and 10 for square and rectangular shapes, respectively. Fig. 2 represent the schematic of ribbed height and rib parameters.

Moghaddami, Shahidi et al. (2012) numerically observed the entropy generation of water- $\mathrm{Al}_{2} \mathrm{O}_{3}$ nanofluid flow through a circular pipe with constant heat flux wall boundary condition in laminar and turbulent regimes. They observed that increasing $\mathrm{Re}$ and nanoparticle concentration outcomes in a decrease in heat transfer entropy generation while it rises the friction entropy generation.

Hassan et al. (2013) examined the entropy generation in nanofluids was evaluated using two different models for conductivity and viscosity. For alumina-water $\left(\mathrm{Al}_{2} \mathrm{O}_{3}-\mathrm{H}_{2} \mathrm{O}\right)$ nanofluid under laminar flow regime in microchannels, it was observed that the ratio of entropy generation for the nanofluid over the base fluid is greater than unity, and the ratio rises with the rise in solid volume fraction.
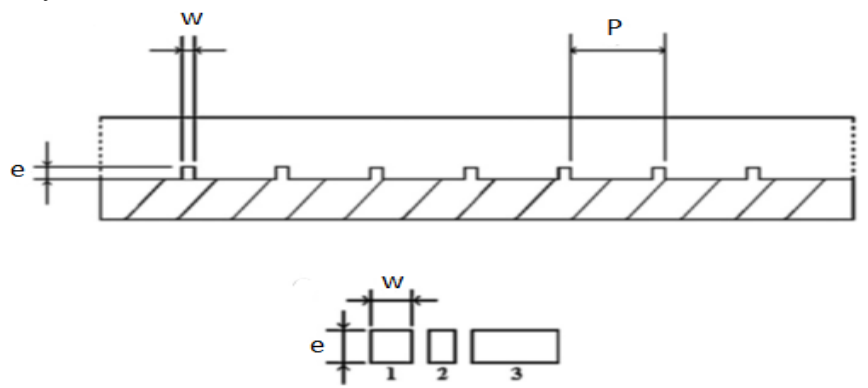

Fig. 2 Schematic of rib channel geometries (Manca, Nardini et al. 2012)

Sohel et al. (2013) analysis the entropy generation of a turbulent flow through the circular microchannel and minichannel heat exchanger is comparatively discussed using two different base fluid and nanofluid at various volume fraction. Entropy generation decreased by the increasing of volume fraction of both type of nanoparticle dispersed in $\mathrm{H}_{2} \mathrm{O}$ and EG. The entropy generation rate ratio in microchannel was lower than the unity and it decreased by the increasing of volume fraction. The entropy generation rate increment at much greater rate by the increasing of the diameter of the flow channel for both microchannel and minichannel. Ting et al. (2013) investigate an analytical analysis for the effect of viscous dissipation on the secondlaw performance of water-alumina nanofluid flow in a circular microchannel subjected to exponentially decaying wall heat flux. The total entropy generation and fluid friction irreversibility in the fluid are overrated when viscous dissipation effect is neglected.

Chen et al. (2014) numerically examined heat transfer performance, viscous dissipation effects and entropy generation behaviour of a fully-developed mixed convection flow of $\mathrm{Al}_{2} \mathrm{O}_{3}$-water nanofluid within a vertical channel with asymmetric heated walls. In performing the simulations, the velocity and temperature fields within the channel have been solved using the differential transformation method (DTM). The equivalent thermal expansion coefficient of the $\mathrm{Al}_{2} \mathrm{O}_{3}$ nanofluid is less than that of pure water.

Kianifar et al. (2014) carried out an analytical analysis to analysis the effects of tube roughness, nanoparticle size, and different thermophysical models on the heat transfer and entropy generation in a flat plate solar collector using $\mathrm{Al}_{2} \mathrm{O}_{3}$ /water nanofluid with volume fraction by $4 \%$ and for constant mass flow rates. $\mathrm{Nu}$ decreases with increasing the volume fraction while an rise in the size of nanoparticles rises the $\mathrm{Nu}$. The trend of changes in outlet temperature and $\mathrm{Nu}$ is exactly opposite, so that the volume fraction and nanoparticle size in which the outlet temperature is maximized can be determined by minimization of the $\mathrm{Nu}$ without doing long calculations. 
Das et al. (2014) show an experimental result within 1 to $2 \%$ between the test data and the predicted values of the heat transfer rate and the overall heat transfer coefficient for water flow in the PHE by the SWEP modelling software. Fig. 3 represents the plate heat exchanger internal view. On the basis of equal pumping power of $0.586 \mathrm{~W}$ while transferring about $2.5 \mathrm{~kW}$ of heat $\mathrm{Al}_{2} \mathrm{O}_{3}$ nanofluid gave a heat transfer surface area reduction of about $0.86 \%$. Although this area reduction is small, further optimization with different heat transfer, flow rates and different volumetric concentration may yield improved surface area reduction.
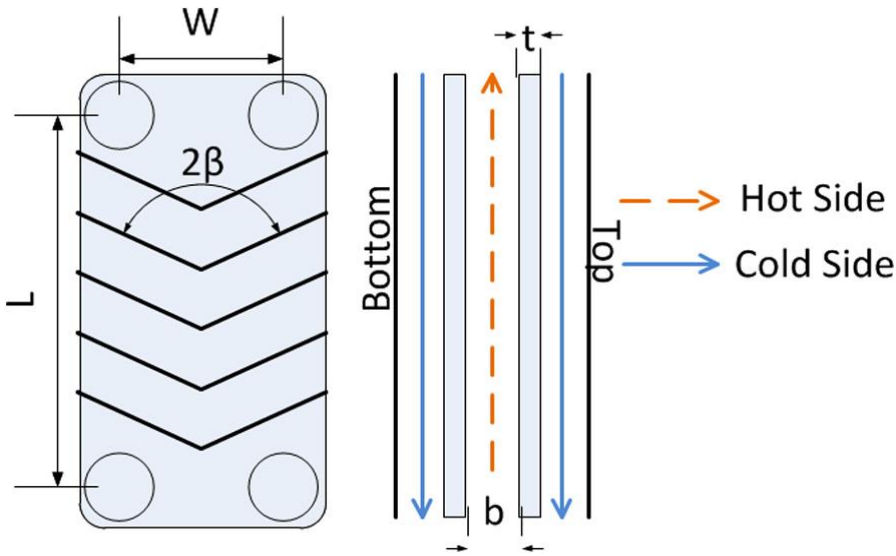

Fig. 3 Plate heat exchanger internal view ( Das et al. 2014)

Hajialigol et al. (2015) examined laminar mixed convection and entropy generation in a three-dimensional microchannel filled with $\mathrm{Al}_{2} \mathrm{O}_{3}$-water nanofluid under a magnetic field. The rise in heat transfer by increasing volume fraction is larger at greater Re. They observed that thermal entropy generation has a major contribution in the total entropy generation compared to frictional and magnetic one. Fig. 4 represent schematic geometry of the physical model.
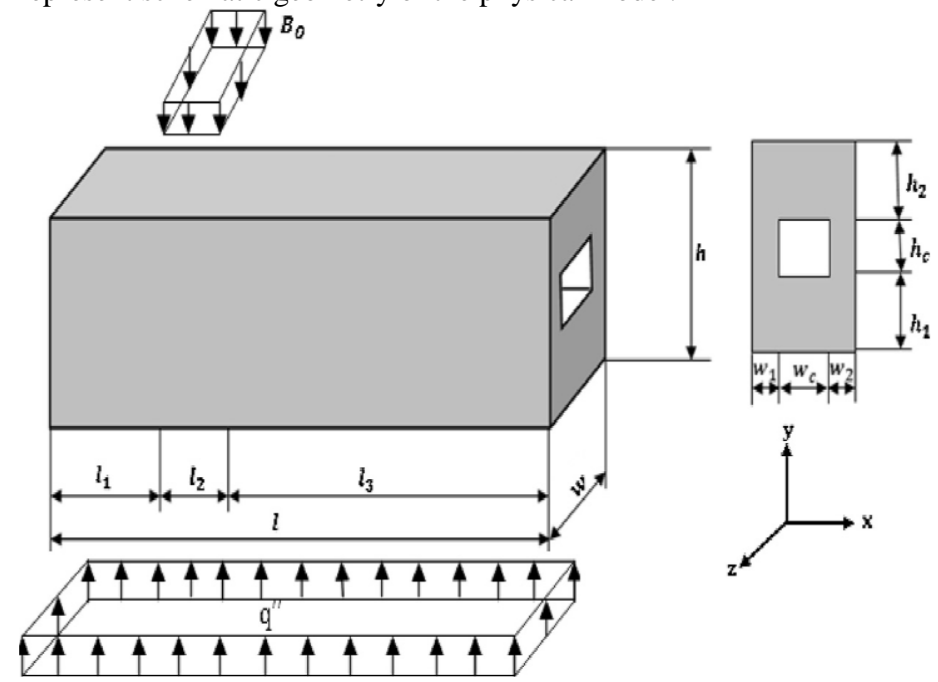

Fig. 4 A schematic geometry of the physical model (Hajialigol et al. 2015)

Shojaeizadeh et al. (2015) investigate the exergy efficiency of a Flatplate solar collector containing $\mathrm{Al}_{2} \mathrm{O}_{3}$-water nanofluid as base fluid. Fig. 5 illustrates schematic of the solar collector. The effect of various parameters like mass flow rate of fluid, nanoparticle volume concentration, collector inlet fluid temperature, solar radiation, and ambient, temperature on the collector exergy is examined. They observed that when nanoparticles are presented in the base fluid the maximum collector exergy efficiency is increment about $0.72 \%$ and also the corresponding optimized values of mass flow rate and collector inlet fluid temperature are decreased about $67.8 \%$ and $1.9 \%$ respectively.

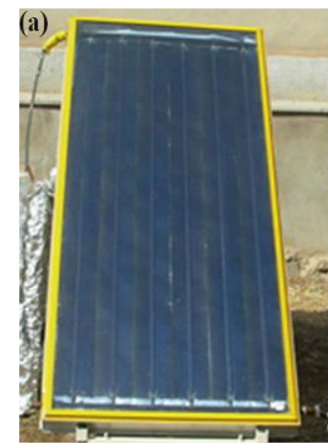

(b)

Fig. 5 Schematic of the solar collector (Shojaeizadeh et al. 2015)

Armaghani et al. (2016) analysed the natural convection heat transfer and entropy generation of Alumina- water nanofluid in baffled Lshaped cavity by numerical method.

Khoshvaght-Aliabadi and Sahamiyan (2016) examined Thermal-hydraulic behaviour of a corrugated minichannels heat sink (CMCHS) using the $\mathrm{Al}_{2} \mathrm{O}_{3}$ /water nanofluid by an experimental approach. Fig. 6 show schematic patterns of CMCHSs and isometric drawing of MCHS. The effects of geometrical parameter (wave-length and wave-amplitude), nanoparticles weight fraction, and mass flow rate are examined. They observed that the $\mathrm{Al}_{2} \mathrm{O}_{3}$ /water nanofluids show a better cooling performance compared to the base fluid.

Said et al. (2016) carried out an experimental research to investigate the thermal performance of a flat plate solar collector using respectively deionized water and water-based $\mathrm{Al}_{2} \mathrm{O}_{3}$-nanofluid with different sizes as the working liquid. They observed that with smaller size of nanoparticles better stability, thermal conductivity as well as better energy and exergy efficiencies are obtained. Fig. 7 represents the flat plate collector with nanofluids flow inside the tubes by Shojaeizadeh and Veysi (2016). They observed that the optimum exergy efficiency and each of corresponding optimum parameters (mass flow rate of fluid, nanoparticle volume concentration and collector inlet temperature) decrease exponentially with increasing $T_{a} / G_{t}$ values (i.e. ambient temperature to solar radiation ratio).

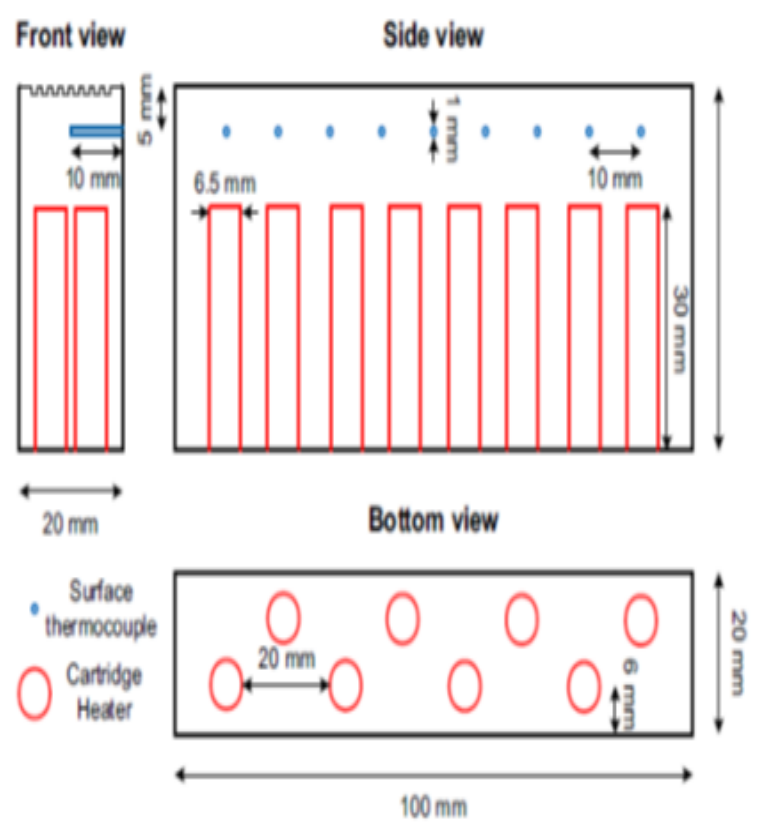

Fig. 6 Schematic patterns of CMCHSs, isometric drawing of MCHS (Khoshvaght-Aliabadi and Sahamiyan 2016) 


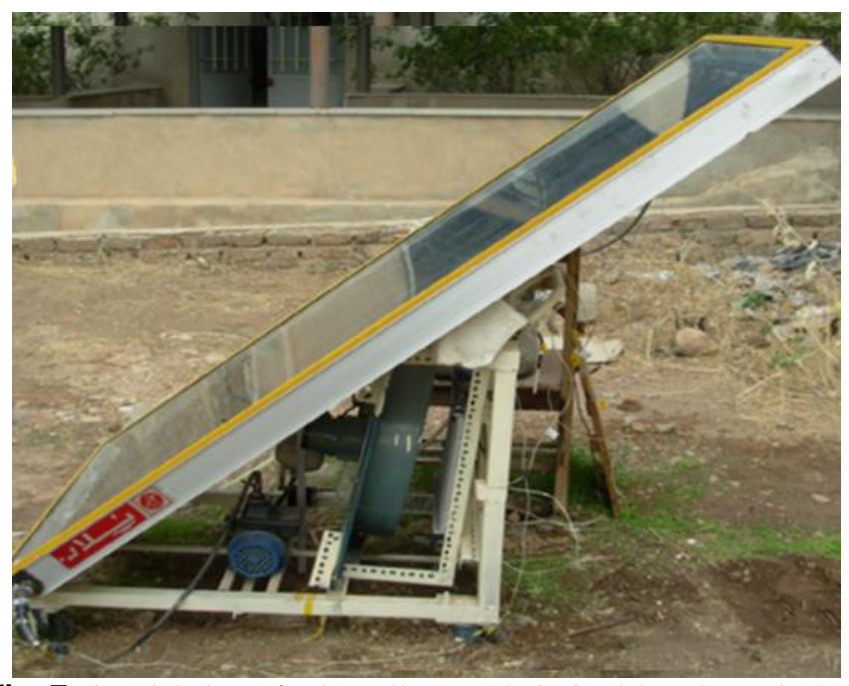

Fig. 7 Pictorial view of solar collector (Shojaeizadeh and Veysi 2016)

Edalatpour and Solano (2017) examined numerically the various parameters of heat transfer in a 30-degree inclined three-dimensional tube-on sheet flat plate solar collector working under conjugated laminar mixed convection. The simulations were performed for water with different concentrations of $\mathrm{Al}_{2} \mathrm{O}_{3}$ nanoparticles. $\mathrm{Nu}$ decreases as the volume fraction of alumina/ water nanofluid rises, whereas when the Re rises, the $\mathrm{Nu}$ also rises. Gangadevi et al. (2017) analysis the PV/T system was experimentally examined with water, $1 \mathrm{wt} \%$ and 2 wt $\%$ of $\mathrm{Al}_{2} \mathrm{O}_{3}$ /water nanofluid. The hybrid PV/T system overall performance totally depends on the suspension sustainability of the coolant used. Their outcomes showed that the PV panel temperature increment up to 70 degrees which may cause the reduction of PV panel life. When circulating the $2 \mathrm{wt} \% \mathrm{Al}_{2} \mathrm{O}_{3}$ /water nanofluid the temperature of the PV panel decreased into 36 degrees.

Rashidi et al. (2018) used a volume of fluid (VOF) model to investigate the potential of $\mathrm{Al}_{2} \mathrm{O}_{3}$-water nanofluid to improve the productivity of a single slope solar still. Moreover, an entropy generation analysis was performed to evaluate the system from the point of view of the second law of thermodynamics. They observed that the maximum values of viscous and thermal entropy generations are happened at the regions around the bottom and top surfaces of the solar still. Both types of entropy generation rise by increasing the solid volume fraction of nanoparticles.

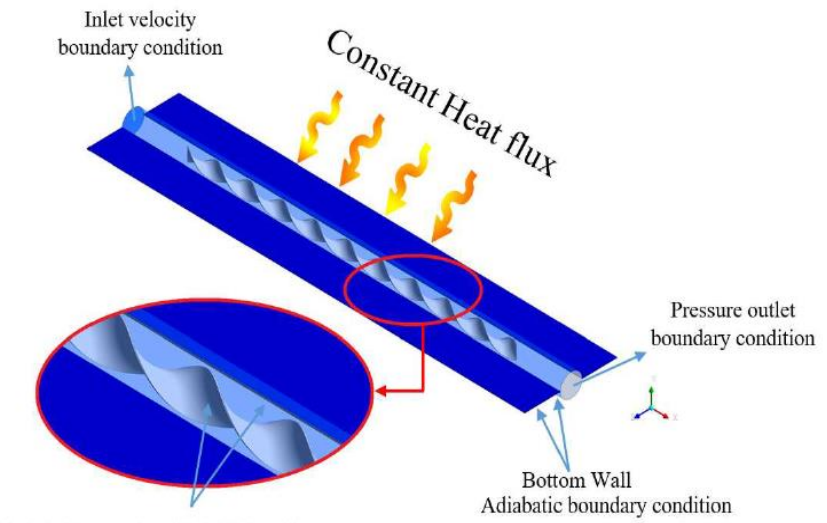

Twisted tape and welded joint surface Two-sided walls boundary condition

Fig. 8 Schematic view of twisted tape (Farshad and Sheikholeslami 2019)

Arora, Fekadu et al. (2019) focuses on a comparative analysis of nanofluids (i.e. $\mathrm{Al}_{2} \mathrm{O}_{3}$-water) and water and their effects on performance of Marquise shaped channel flat plate solar collector. The observed outcomes illustrate that their collecting efficiencies are all superior to that of water. The exergy efficiency of the water $/ \mathrm{Al}_{2} \mathrm{O}_{3}$ nanofluid is also greater compared to that of water. Farshad and Sheikholeslami (2019) investigates numerically exergy loss and heat transfer within a solar collector shown in Fig. 8 with insertion of helical tape inside the pipe. $\mathrm{Al}_{2} \mathrm{O}_{3}$-water nanofluid is selected among other nanofluids which are more common in solar application due to its greater usage and lower price. Also they observed that the adding nanoparticles leads to the exergy loss reduction because of the growth of particles interaction.

Table. 1 represents the previous investigation on exergy analysis of $\mathrm{Al}_{2} \mathrm{O}_{3}$ based nanofluid flow through conduits.

Table 1 Previous investigation on exergy analysis of $\mathrm{Al}_{2} \mathrm{O}_{3}$ based nanofluid flow through conduits.

\begin{tabular}{|c|c|c|}
\hline Author (s) & Description & Conclusion \\
\hline $\begin{array}{l}\text { Singh et al. } \\
(2010)\end{array}$ & $\begin{array}{l}\text { Microchannel } \\
\text { and } \\
\text { conventional } \\
\text { channels with } \\
\text { laminar and } \\
\text { turbulent flow }\end{array}$ & $\begin{array}{l}\text { They observed that after a } \\
\text { particular diameter the entropy } \\
\text { generation ratio becomes } \\
\text { constant or rises very slowly. }\end{array}$ \\
\hline $\begin{array}{l}\text { Chen and Ding } \\
\text { (2011) }\end{array}$ & $\begin{array}{l}\text { Microchannel } \\
\text { heat sink }\end{array}$ & $\begin{array}{l}\text { Their investigation showed that } \\
\text { the temperature distribution of } \\
\text { the channel wall is found to be } \\
\text { practically insensitive to the } \\
\text { inertial effect, while the fluid } \\
\text { temperature distribution and the } \\
\text { total thermal resistance alter } \\
\text { noticeably due to the inclusion } \\
\text { of flow inertial force. }\end{array}$ \\
\hline $\begin{array}{l}\text { Hung et al. } \\
(2012)\end{array}$ & $\begin{array}{l}\text { Circular } \\
\text { microchannels }\end{array}$ & $\begin{array}{l}\text { Incorporating the viscous } \\
\text { dissipation effect, both thermal } \\
\text { performance and exergetic } \\
\text { effectiveness for forced } \\
\text { convection of nanofluid in } \\
\text { microchannels }\end{array}$ \\
\hline $\begin{array}{l}\text { Manca et al. } \\
(2012)\end{array}$ & $\begin{array}{l}\text { Ribbed } \\
\text { channels }\end{array}$ & $\begin{array}{l}\text { The highest values of overall } \\
\text { performance parameters for } \\
\text { pitch ratio is 8.0. }\end{array}$ \\
\hline $\begin{array}{l}\text { Moghaddami } \\
\text { et al. (2012) }\end{array}$ & $\begin{array}{l}\text { Turbulent and } \\
\text { laminar } \\
\text { regimes }\end{array}$ & $\begin{array}{l}\text { It is observed that unlike the } \\
\text { laminar regime, the total } \\
\text { entropy generation of water- } \\
\mathrm{Al}_{2} \mathrm{O}_{3} \text { nanofluid flow could be } \\
\text { more than that of pure water in } \\
\text { high Res, restricting the } \\
\text { advantage of using water- } \mathrm{Al}_{2} \mathrm{O}_{3} \\
\text { nanofluid. }\end{array}$ \\
\hline $\begin{array}{l}\text { Hassan et al. } \\
(2013)\end{array}$ & $\begin{array}{l}\text { Micro- and } \\
\text { minichannels }\end{array}$ & $\begin{array}{l}\text { The application of } \\
\text { alumina-water nanofluids } \\
\text { to a minichannel is } \\
\text { advantageous. }\end{array}$ \\
\hline $\begin{array}{l}\text { Sohel et al. } \\
(2013)\end{array}$ & $\begin{array}{l}\text { Circular } \\
\text { microchannel } \\
\text { and } \\
\text { minichannel } \\
\text { heat sink } \\
\end{array}$ & $\begin{array}{l}\text { Copper nanoparticle generates } \\
\text { much lower entropy than the } \\
\text { alumina nanoparticle. }\end{array}$ \\
\hline $\begin{array}{l}\text { Tiew et al. } \\
(2013)\end{array}$ & $\begin{array}{l}\text { Circular } \\
\text { microchannel }\end{array}$ & $\begin{array}{l}\text { Heat transfer irreversibility of } \\
\text { nanofluid decreases at small Re, } \\
\text { suggesting an ideal operating } \\
\text { region to improve the exergetic } \\
\text { effectiveness of the flow when } \\
\text { the heat transfer irreversibility }\end{array}$ \\
\hline
\end{tabular}




\begin{tabular}{|c|c|c|c|c|c|}
\hline & & is the dominant source of & & & $\mathrm{Al}_{2} \mathrm{O}_{3} /$ water nanofluid rises. \\
\hline & & entropy generation in the flow. & Gangadevi & Hybrid & The result shows that by using 2 \\
\hline $\begin{array}{l}\text { Chen et al. } \\
(2014)\end{array}$ & $\begin{array}{l}\text { Vertical } \\
\text { channels }\end{array}$ & $\begin{array}{l}\text { By contrast, in the regions of } \\
\text { the flow field characterized by a } \\
\text { greater and more uniform } \\
\text { velocity distribution, i.e., the } \\
\text { central region of the channel, } \\
\text { the total entropy generation rate } \\
\text { is dominated by the effects of } \\
\text { fluid heat transfer }\end{array}$ & al. (2017) & $\begin{array}{l}\mathrm{PV} / \text { spiral } \\
\text { flow thermal } \\
\text { collector }\end{array}$ & $\begin{array}{l}\text { wt } \% \mathrm{Al}_{2} \mathrm{O}_{3} / \text { water nanofluid the } \\
\text { electrical efficiency, thermal } \\
\text { efficiency and overall efficiency } \\
\text { of the PVT system enhanced by } \\
13 \%, \quad 45 \% \text {, and } 58 \% \\
\text { respectively compared with } \\
\text { water and } 1 \mathrm{wt} \% \text { of } \mathrm{Al}_{2} \mathrm{O}_{3} \text {-water } \\
\text { nanofluid. }\end{array}$ \\
\hline $\begin{array}{l}\text { Mahian et al. } \\
\text { (2014) }\end{array}$ & $\begin{array}{l}\text { Solar } \\
\text { collector }\end{array}$ & $\begin{array}{l}\text { The effects of roughness in } \\
\text { entropy generation are more } \\
\text { important when the solar } \\
\text { radiation and ambient }\end{array}$ & $\begin{array}{l}\text { Rashidi et al. } \\
\text { (2018) }\end{array}$ & $\begin{array}{l}\text { Single slope } \\
\text { solar still }\end{array}$ & $\begin{array}{l}\text { The amounts of the evaporation } \\
\text { and condensation heat transfers } \\
\text { are improved in the still by } \\
\text { adding the } \mathrm{Al}_{2} \mathrm{O}_{3} \text { nanoparticles. }\end{array}$ \\
\hline & & $\begin{array}{l}\text { temperature } \\
\text { Decreases }\end{array}$ & $\begin{array}{l}\text { Arora et al. } \\
(2019)\end{array}$ & $\begin{array}{l}\text { Marquise } \\
\text { shaped }\end{array}$ & $\begin{array}{l}\text { The innovative design of the } \\
\text { absorber plate (marquise shaped }\end{array}$ \\
\hline $\begin{array}{l}\text { Ray et al. } \\
(2014)\end{array}$ & $\begin{array}{l}\text { Compact } \\
\text { minichannel }\end{array}$ & $\begin{array}{l}\text { Copper oxide gave a } 4.78 \% \\
\text { reduction in the volumetric flow } \\
\text { rate, and } 1.73 \% \text { reduction in the }\end{array}$ & & $\begin{array}{l}\text { channel solar } \\
\text { flat-plate } \\
\text { collector }\end{array}$ & $\begin{array}{l}\text { channel) and use of nanofluids } \\
\text { enhances the efficiency of solar } \\
\text { flat collector. }\end{array}$ \\
\hline & & $\begin{array}{l}\text { required pumping power, when } \\
\text { compared with the base fluid, } \\
\text { which was EG/W. }\end{array}$ & $\begin{array}{l}\text { Farshad and } \\
\text { Sheikholeslami } \\
\text { (2019) }\end{array}$ & $\begin{array}{l}\text { Solar } \\
\text { collector } \\
\text { utilizing }\end{array}$ & $\begin{array}{l}\text { Secondary flow intensifies with } \\
\text { rise of diameter ratio while } \\
\text { exergy loss reduces with it. }\end{array}$ \\
\hline Hajialigol et & $3-\mathrm{D}$ & The maximum dimensionless & & twisted tape & \\
\hline
\end{tabular}

\subsection{Exergy Analysis of $\mathrm{CuO}$ based nanofluids flow through conduits}

Chein and Huang (2005) analyzed performances of MCHS using nanofluids as the coolant. Fig. 9 signify Geometric configuration of MCHS. The enhancement is due to the rise in thermal conductivity of coolant and the nanoparticle thermal dispersion effect. The other advantage in using nanofluid as coolant in the MCHS is that there is no extra pressure drop produced since the nanoparticle is small and particle volume fraction is low.

$\mathrm{Li}$ and Kleinstreuer (2008) compared two effective thermal conductivity models for nanofluids where the new model, based on Brownian-motion induced micro-mixing, achieved good agreements with the currently available experimental data sets. The thermal performance rises with volume fraction; but the extra pressure drop, or pumping power, will somewhat decrease the beneficial effects. MCHS with nanofluids are expected to be good candidates for the next generation of cooling devices.

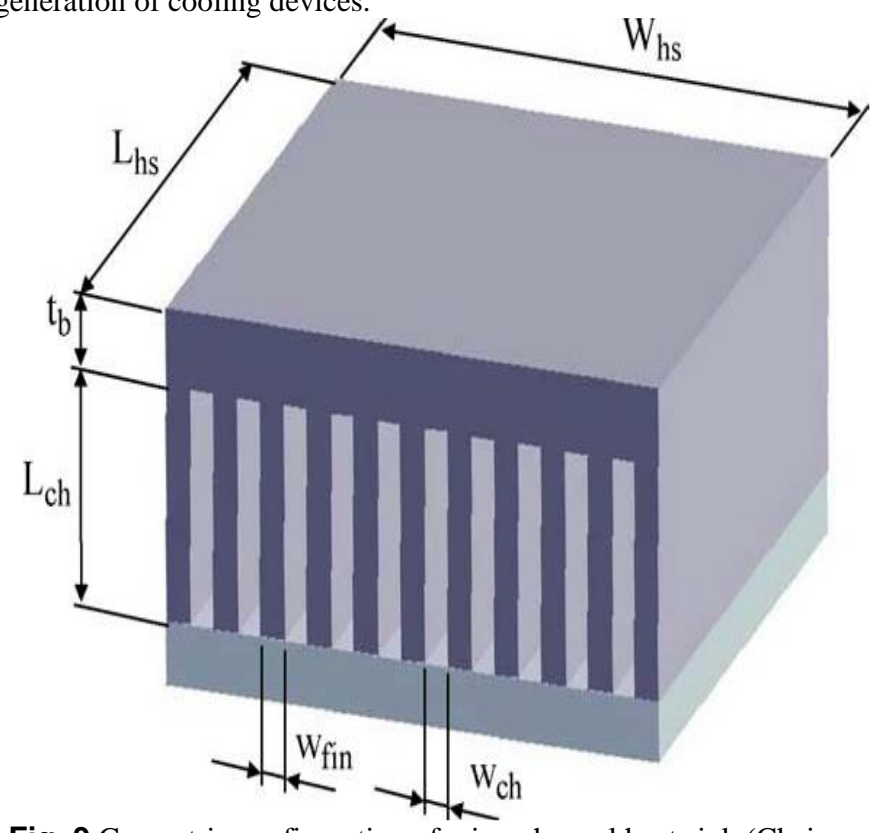

Fig. 9 Geometric configuration of microchannel heat sink (Chein and Huang 2005) 
Jie Li (2010) examined entropy generation in laminar microchannel flow with a computer model, which was validated with benchmark analytical and numerical outcomes. Nanofluids and pure water were selected as potential coolants for three cases of trapezoidal microchannels with the same hydraulic diameter and base angle but different aspect ratios. They observed that the entropy generation decreases with the rise in the fluid inlet temperature, which reduces local temperature gradients.

Khorasanizadeh et al. (2012) analysis Irrespective of the location of the conductive baffle, $\mathrm{Nu}_{\mathrm{m}}$ rises by increasing $\mathrm{Ra}$ number and $\varphi$. For $\mathrm{Ra}=10^{4}$ the conduction is the dominant mechanism of heat transfer and as the baffle moves toward the centre of the cavity the conduction mitigates, thus $\mathrm{Nu}_{\mathrm{m}}$ decreases. For $\mathrm{Ra}=10^{5}$ and $\mathrm{Ra}=10^{6}$ by displacing the baffle toward the centre of the cavity the convection gets stronger and the trend for $\mathrm{Nu}_{\mathrm{m}}$ is to rise. The total entropy generation decreases by increasing the $\mathrm{Ra}$ for all volume fractions and all positions of conductive baffle.

Khairul et al. (2014) focused on the benefits of using $\mathrm{CuO} /$ water nanofluids in a corrugated plate heat exchanger. Analytical outcomes reveal that, $\mathrm{CuO} /$ water nanofluids could reduce the exergy destruction by $24 \%, 16.25 \%$ and $8 \%$ for 1.5 vol. $\%, 1.0$ vol. $\%$ and 0.5 vol. $\%$ of nanoparticles, respectively compared to water. Therefore, average $34 \%$, $22 \%$ and $12 \%$ enhanced exergetic heat transfer effectiveness is found for $1.5 \mathrm{vol}$. \%, $1.0 \mathrm{vol}$. \% and $0.5 \mathrm{vol}$. \% of nanoparticles compare to water. Michael and Iniyan (2015) tested a novel photovoltaic thermal collector were fabricated and its performance using $0.05 \%$ volume fraction $\mathrm{CuO} /$ water nanofluid. The nanofluid has been proved to rise the thermal efficiency up to $45.76 \%$.

Chamkha et al. (2017) numerically examined effects of the presence of a heat sink and a heat source and their lengths and locations and the entropy generation on mixed convection of a $\mathrm{Cu}$-water nanofluid in a porous media filled in a lid-driven square enclosure with partial slip and subjected to a magnetic field. Increasing the volume fraction of the nanoparticles decreases the convective heat transfer inside the porous cavity for all ranges of the heat sink and the heat source lengths. Abdollahi-Moghaddam et al. (2018) experimentally examined the heat transfer enhancement and pressure drop of $\mathrm{CuO} /$ water nanofluid. The experiments were performed in a horizontal tube in which the wall had a constant temperature. The heat transfer coefficient and pressure drop of nanoparticle volume fraction of $0 \%$ to $0.7 \%$ were measured at various Res. The outcomes showed that heat transfer of nanofluid rises by increasing $\mathrm{Re}$ and volume fraction of nanoparticles.

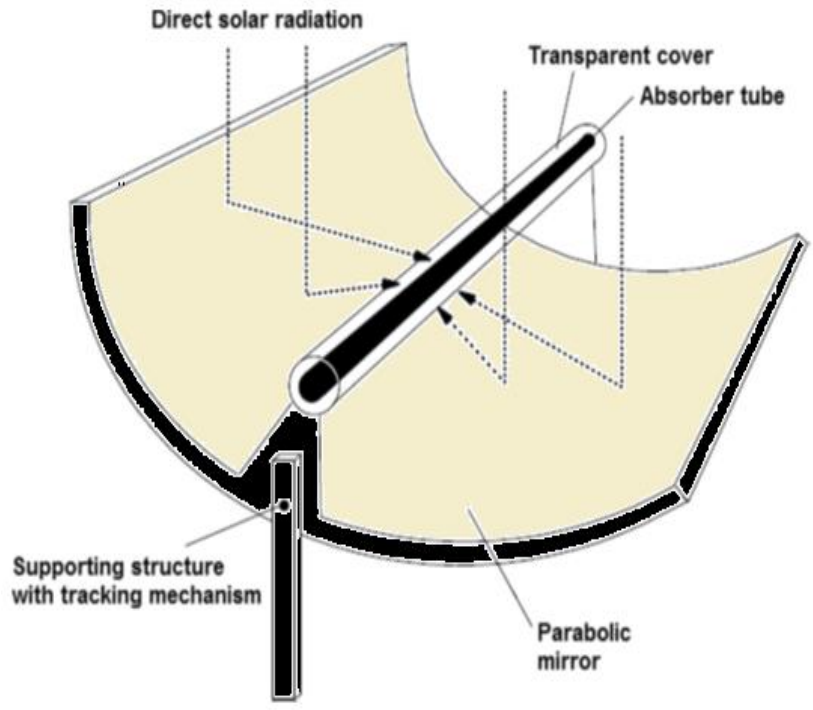

Fig. 10 Parabolic trough collector (Allouhi et al. 2018)
Allouhi et al. (2018) examine the benefits of using nanofluids as working fluids in parabolic trough collectors for medium and high temperature applications. Energy and exergy analyses were carried out based on real fluctuating operating conditions. Fig. 10 illustrate parabolic trough collector. The exergy efficiency varied between $3.05 \%$ and $8.5 \%$ for the base fluid case and gets improved more remarkably when nanofluids are employed. The peak exergy efficiency is attained by the $\mathrm{CuO}$ based nanofluid and is about $9.05 \%$. Bellos et al. (2018) investigates the dispersion of $\mathrm{CuO}$ nanoparticles in Syltherm 800 and in nitrate molten salt for operation in a parabolic trough collector. Moreover, it is found that the maximum exergetic efficiency is achieved for the molten salt case when the inlet temperature is equal to $650 \mathrm{~K}$ and then the exergetic efficiency is about $38.4 \%$.

Table. 2 represents the previous investigation on exergy analysis of nanofluids flow based through conduits. Table. 3 shows the previous investigation on exergy analysis of $\mathrm{CuO}$ based nanofluid flow through conduits.

Table 2 Previous investigation on exergy analysis of nanofluids flow based through conduits.

\begin{tabular}{|c|c|c|}
\hline \multicolumn{3}{|c|}{ Electrical efficiency of the $P V / T$ collector } \\
\hline Author (s) & Nanofluids used & Major findings \\
\hline \multirow[t]{5}{*}{$\begin{array}{l}\text { Michael and } \\
\text { Iniyan (2015) }\end{array}$} & $\mathrm{CuO}$ with glazing & $\begin{array}{l}\text { Electrical efficiency is } 5.3 \% \\
\text { at } 10: 30 \text { max. } 5.8 \% \text { at } 12: 15 \\
\text { and min. } 3.2 \% \text { at } 15: 30\end{array}$ \\
\hline & $\begin{array}{l}\mathrm{CuO} \quad \text { without } \\
\text { glazing }\end{array}$ & $\begin{array}{l}\text { Electrical efficiency is } 6.4 \% \\
\text { at } 10: 00 \text { max. } 7.4 \% \text { at } 12: 15 \\
\text { and min. } 4.8 \% \text { at } 15: 30\end{array}$ \\
\hline & Water with glazing & $\begin{array}{l}\text { Electrical efficiency is } 5 \% \text { at } \\
10: 30 \text { max. } 5.9 \% \text { at } 12: 15 \\
\text { and min. } 3.2 \% \text { at } 15: 30\end{array}$ \\
\hline & $\begin{array}{l}\text { Water without } \\
\text { glazing }\end{array}$ & $\begin{array}{l}\text { Electrical efficiency is } 7.8 \% \\
\text { at } 10: 30 \text { max. } 8.4 \% \text { at } 12: 15 \\
\text { and min. } 5.2 \% \text { at } 15: 30\end{array}$ \\
\hline & Reference PV & $\begin{array}{l}\text { Electrical efficiency is } 7.9 \% \\
\text { at } 10: 30 \max .8 .6 \% \text { at } 12: 00 \\
\text { and min. } 5.1 \% \text { at } 15: 30\end{array}$ \\
\hline \multicolumn{3}{|c|}{ Thermal efficiency of the PV/T collector } \\
\hline & Water with glazing & $\begin{array}{l}\text { Thermal efficiency is } 16 \% \text { at } \\
10: 00 \text { max. } 17 \% \text { at } 12: 00 \text { and } \\
\text { min. } 13 \% \text { at } 15: 30\end{array}$ \\
\hline & $\begin{array}{l}\text { Water without } \\
\text { glazing }\end{array}$ & $\begin{array}{l}\text { Thermal efficiency is } 14 \% \text { at } \\
10: 00 \text { max. } 15 \% \text { at } 12: 30 \text { and } \\
\text { min. } 13 \% \text { at } 15: 30\end{array}$ \\
\hline & $\mathrm{CuO}$ with glazing & $\begin{array}{l}\text { Thermal efficiency is } 20 \% \text { at } \\
10: 00 \text { max. } 27 \% \text { at } 12: 45 \text { and } \\
\text { min. } 21 \% \text { at } 15: 30\end{array}$ \\
\hline & $\begin{array}{l}\mathrm{CuO} \quad \text { without } \\
\text { glazing }\end{array}$ & $\begin{array}{l}\text { Thermal efficiency is } 18 \% \text { at } \\
10: 00 \text { max. } 23 \% \text { at } 12: 45 \text { and } \\
\text { min. } 18 \% \text { at } 15: 30\end{array}$ \\
\hline \multicolumn{3}{|c|}{ Overall efficiency of the PV/T collector } \\
\hline & $\mathrm{CuO}$ with glass & $\begin{array}{l}\text { Overall efficiency is } 31 \% \text { at } \\
10: 00 \text { max. } 42 \% \text { at } 12: 45 \text { and } \\
\text { min. } 31 \% \text { at } 15: 30\end{array}$ \\
\hline & $\mathrm{CuO}$ without glass & $\begin{array}{l}\text { Overall efficiency is } 35 \% \text { at } \\
10: 00 \text { max. } 43 \% \text { at } 12: 15 \text { and } \\
\text { min. } 31 \% \text { at } 15: 30\end{array}$ \\
\hline & Water with glass & $\begin{array}{l}\text { Overall efficiency is } 29 \% \text { at } \\
10: 00 \text { max. } 33 \% \text { at } 12: 30 \text { and } \\
\text { min. } 25 \% \text { at } 15: 30\end{array}$ \\
\hline & $\begin{array}{l}\text { Water without } \\
\text { glass }\end{array}$ & $\begin{array}{l}\text { Overall efficiency is } 35 \% \text { at } \\
10: 00 \text { max. } 37 \% \text { at } 12: 00 \text { and } \\
\text { min. } 30 \% \text { at } 15: 30\end{array}$ \\
\hline & Reference PV & $\begin{array}{l}\text { Overall efficiency is } 20 \% \text { at } \\
10: 00 \text { max. } 22 \% \text { at } 12: 15 \text { and }\end{array}$ \\
\hline
\end{tabular}


$\min .18 \%$ at $15: 30$

Table 3 Previous investigation on exergy analysis of $\mathrm{CuO}$ based nanofluid flow through conduits.

\begin{tabular}{|c|c|c|}
\hline Author (s) & Description & Conclusion \\
\hline $\begin{array}{l}\text { Chein and } \\
\text { Huang } \\
(2005)\end{array}$ & $\begin{array}{l}\text { Microchannel } \\
\text { heat sink }\end{array}$ & $\begin{array}{l}\text { The advantage in using nanofluid as } \\
\text { coolant in the microchannel heat } \\
\text { sink is that there is no extra pressure } \\
\text { drop produced since the nanoparticle } \\
\text { is small and particle volume fraction } \\
\text { is low. }\end{array}$ \\
\hline $\begin{array}{l}\mathrm{Li} \text { and } \\
\text { Kleinstreu } \\
\text { er (2008) }\end{array}$ & $\begin{array}{l}\text { Trapezoidal } \\
\text { microchannel }\end{array}$ & $\begin{array}{l}\text { Microchannel heat sinks with } \\
\text { nanofluids are expected to be good } \\
\text { candidates for the next generation of } \\
\text { cooling devices. }\end{array}$ \\
\hline $\begin{array}{l}\text { Jie and } \mathrm{Li} \\
(2010)\end{array}$ & $\begin{array}{l}\text { Trapezoidal } \\
\text { microchannels } \\
\text { for steady } \\
\text { laminar flow }\end{array}$ & $\begin{array}{l}\text { Employing certain nanofluids as } \\
\text { coolants may further benefit the } \\
\text { minimization of entropy generation } \\
\text { in microchannel heat sinks. }\end{array}$ \\
\hline $\begin{array}{l}\text { Khorasani } \\
\text { zadeh et } \\
\text { al. }(2012)\end{array}$ & $\begin{array}{l}\text { Cavity with an } \\
\text { embedded } \\
\text { conductive } \\
\text { baffle }\end{array}$ & $\begin{array}{l}\text { Due to enhanced viscose effects } \\
\text { with improved convection, the } \\
\text { maximum entropy generation occurs } \\
\text { when the baffle is at the middle of } \\
\text { the bottom wall. The Bejan number } \\
\text { rises with increasing Ra number, } \\
\text { since heat transfer irreversibility } \\
\text { rises while viscose irreversibility } \\
\text { decreases. }\end{array}$ \\
\hline $\begin{array}{l}\text { Khairul et } \\
\text { al. (2014) }\end{array}$ & $\begin{array}{l}\text { Corrugated } \\
\text { plate heat } \\
\text { exchanger }\end{array}$ & $\begin{array}{l}\text { The performance of a heat } \\
\text { exchanger can be enhanced by } \\
\text { converting the working fluid with } \\
\text { nanofluids. }\end{array}$ \\
\hline $\begin{array}{l}\text { (Michael } \\
\text { and } \\
\text { Iniyan } \\
\text { 2015) }\end{array}$ & $\begin{array}{l}\text { Copper sheet } \\
\text { laminated } \\
\text { photovoltaic } \\
\text { thermal } \\
\text { collector }\end{array}$ & $\begin{array}{l}\text { The reduced electrical efficiency } \\
\text { using the } \mathrm{CuO} / \text { water nanofluid, the } \\
\text { electrical and thermal efficiencies of } \\
\text { the discussed solar } \\
\text { photovoltaic/thermal collector can } \\
\text { be further improved if the heat } \\
\text { exchanger is re-designed for the new } \\
\text { nanofluid. }\end{array}$ \\
\hline $\begin{array}{l}\text { Chamkha } \\
\text { et al. } \\
(2017)\end{array}$ & $\begin{array}{l}\text { Lid-driven } \\
\text { square porous } \\
\text { enclosure with } \\
\text { partial slip }\end{array}$ & $\begin{array}{l}\text { Increasing the volume fraction of } \\
\text { the nanoparticles decreases the } \\
\text { convective heat transfer inside the } \\
\text { porous cavity for all ranges of the } \\
\text { heat sink and the heat source } \\
\text { lengths. }\end{array}$ \\
\hline $\begin{array}{l}\text { Abdollahi } \\
- \\
\text { Moghadd } \\
\text { am et al. } \\
(2018)\end{array}$ & $\begin{array}{l}\text { Horizontal } \\
\text { tube }\end{array}$ & $\begin{array}{l}\text { Heat transfer of nanofluid rises by } \\
\text { increasing Re and volume fraction } \\
\text { of nanoparticles. }\end{array}$ \\
\hline $\begin{array}{l}\text { Bellos et } \\
\text { al. (2018) }\end{array}$ & $\begin{array}{l}\text { Parabolic } \\
\text { trough } \\
\text { collector }\end{array}$ & $\begin{array}{l}\text { The use of Syltherm } 800-\mathrm{CuO} \text { leads } \\
\text { to } 0.65 \% \text { mean thermal } \\
\text { enhancement compared to pure } \\
\text { Syltherm, while the use of molten } \\
\text { salt- } \mathrm{CuO} \text { leads only to } 0.13 \% \text { mean } \\
\text { thermal efficiency enhancement. }\end{array}$ \\
\hline
\end{tabular}

\subsection{Exergy analysis of $\mathrm{TiO}_{2}$ based nanofluids flow through conduits:}

Leong et al. (2012) carried out an analytical investigation on the entropy generation of a nanofluid flow through a circular tube with a constant wall temperature. Total dimensionless entropy generation is reduced with nanoparticle volume fractions. About $10.8 \%$ reduction is observed with an addition of $7 \%$ alumina volume fraction compared to base fluid. About $9.7 \%$ reduction is observed for $4 \%$ titanium dioxide nanofluid. Titanium dioxide nanofluids offer lower total dimensionless entropy generation compared to that of alumina nanofluids.

Mahian et al. (2013) investigate analytical analysis of the second law of thermodynamics to the effect of using $\mathrm{TiO}_{2}$-water nanofluid (up to $2 \mathrm{vol} \%$ ) on entropy generation between two rotating cylinders in the presence of magneto hydrodynamic flow. The outcomes for the local entropy generation analysis reveal that entropy generation is highest near the inner cylinder due to the maximum gradients of velocity and temperature. It also was found that the rise in the Hartmann number outcomes in an rise in the average entropy generation number.

Said et al. (2015) found that thermal conductivity improvement is directly related to the volume fraction and enhances up to $6 \%$ with $0.3 \mathrm{vol} \%$ of $\mathrm{TiO}_{2}$. Also the energy efficiency increment by $76.6 \%$ for $0.1 \mathrm{vol} \%$ and $0.5 \mathrm{~kg} / \mathrm{min}$, whereas the highest exergy efficiency achieved is $16.9 \%$ for $0.1 \mathrm{vol} \%$ and $0.5 \mathrm{~kg} / \mathrm{min}$, using the nanofluids in comparison to the water. The solar collector efficiency using the $\mathrm{TiO}_{2}$ nanoparticle has greater energy and exergy efficiencies than water.

Khaleduzzaman et al. (2016) experimentally analysis exergy and entropy generation of $\mathrm{TiO}_{2}$-water nanofluid for cooling of a water block as an electronic device. The organized $\mathrm{TiO}_{2}-$ water nanofluid was passed through the water block heat sink with the concentrations of 0.10 vol. \%. Exergy outlet, exergy gain, and exergy efficiency were found to be greater in the case of nanofluid. However, exergy efficiency and exergy outlet were increment by the rise of flow rate. Besides, the exergy gain was fallen with the rise of flow rate of coolant.

Yazdanifard et al. (2017) analysis a linear parabolic trough $\mathrm{CPV} / \mathrm{T}$ system shown in Fig. 11 Besides, the effects of various geometrical parameters, including concentration ratio, pipe length, and pipe diameter, on the system performance in laminar and turbulent flow regimes were examined. The outcomes showed that with increasing concentration ratio, the PV and outlet temperatures rise in both flow regimes. The total energy efficiency in turbulent flow rises, while the total energy efficiency in laminar flow first rises, and then decreases at a particular concentration ratio.

Qi et al. (2018) experimentally examined and analysed heat transfer and flow behaviour of $\mathrm{TiO}_{2}-\mathrm{H}_{2} \mathrm{O}$ nanofluids in a circular tube with rotating and static built-in twisted tapes by exergy efficiency. $\mathrm{TiO}_{2}-\mathrm{H}_{2} \mathrm{O}$ nanofluids in circular tube with rotating twisted tape shows an excellent enhancement in heat transfer, which can rise the heat transfer by $13.1 \%$ at best compared with nanofluids in circular tube with static built-in twisted tape at the same condition. The exergy efficiency of the circular tube with twisted tape is greater than that of circular tube under the same pumping power and pressure drop, while it shows deterioration under the same mass flow rate. Zhao et al. (2019) experimentally examined the flow and heat transfer behaviour of $\mathrm{TiO}_{2}-\mathrm{H}_{2} \mathrm{O}$ nanofluids in $\mathrm{CPU}$ heat sink. An exergy efficiency evaluation plot is developed and can guide the working condition and nanoparticle concentration choice.

Table. 4 shows the previous investigation on exergy analysis of $\mathrm{TiO}_{2}$ based nanofluid flow through conduits.

Table 4 Previous investigation on exergy analysis of $\mathrm{TiO}_{2}$ based nanofluid flow through conduits.

\begin{tabular}{|l|l|l|}
\hline Author $(s)$ & Description & \multicolumn{1}{|c|}{ Conclusion } \\
\hline $\begin{array}{l}\text { Leong et al. } \\
(2012)\end{array}$ & $\begin{array}{l}\text { Nanofluid } \\
\text { flow in A } \\
\text { circular tube }\end{array}$ & $\begin{array}{l}\text { Titanium dioxide nanofluids offer } \\
\text { lower total dimensionless entropy } \\
\text { generation compared to that of } \\
\text { alumina nanofluids. }\end{array}$ \\
\hline $\begin{array}{l}\text { Mahian et } \\
\text { al. (2013) }\end{array}$ & $\begin{array}{l}\text { Two rotating } \\
\text { cylinders with } \\
\text { magnetohydro } \\
\text { dynamic flow }\end{array}$ & $\begin{array}{l}\text { With respect to the second law of } \\
\text { thermodynamics, using nanofluids } \\
\text { for the flow between two rotating } \\
\text { cylinders in the presence of a }\end{array}$ \\
\hline
\end{tabular}




\begin{tabular}{|c|c|c|}
\hline & & $\begin{array}{l}\text { magneto-hydrodynamic field is } \\
\text { suggested only at low Brinkman } \\
\text { numbers. }\end{array}$ \\
\hline $\begin{array}{l}\text { Said et al. } \\
(2015)\end{array}$ & $\begin{array}{l}\text { Flat plate } \\
\text { solar collector }\end{array}$ & $\begin{array}{l}\text { The solar collector efficiency using } \\
\text { the } \mathrm{TiO}_{2}-\mathrm{H}_{2} \mathrm{O} \text { nanofluid has } \\
\text { greater energy and exergy } \\
\text { efficiencies than water. }\end{array}$ \\
\hline $\begin{array}{l}\text { Khaleduzz } \\
\text { et al. } \\
(2016)\end{array}$ & Water block & $\begin{array}{l}\text { Based on exergy (outlet exergy } \\
\text { increment } 87 \% \text { ) and pressure drop } \\
\text { (increment } 47.93 \% \text { ) values, } 1.5 \\
\text { l/min flow rate of } \mathrm{TiO}_{2}-\mathrm{H}_{2} \mathrm{O} \\
\text { nanofluid was found as the optimal } \\
\text { flow rate in terms of performance. }\end{array}$ \\
\hline $\begin{array}{l}\text { Yazdanifar } \\
\text { d et al. } \\
(2017)\end{array}$ & $\begin{array}{l}\text { Photovoltaic/t } \\
\text { hermal } \\
\text { system }\end{array}$ & $\begin{array}{l}\text { Employing phase change materials } \\
\text { or thermoelectric devices for } \\
\text { cooling purpose, and examining } \\
\text { different nanofluids such as hybrid } \\
\text { nanofluids, or nanofluids contained } \\
\text { graphene, nanorods, and nanotubes } \\
\text { particles in CPV/T systems are } \\
\text { strongly recommended. }\end{array}$ \\
\hline $\begin{array}{l}\text { Qi et al. } \\
(2018)\end{array}$ & $\begin{array}{l}\text { Rotating } \\
\text { twisted tape }\end{array}$ & $\begin{array}{l}\mathrm{TiO}_{2}-\mathrm{H}_{2} \mathrm{O} \text { nanofluids in circular } \\
\text { tube with rotating twisted tape } \\
\text { shows an excellent enhancement in } \\
\text { heat transfer, which can rise the } \\
\text { heat transfer by } 13.1 \% \text { at best } \\
\text { compared with nanofluids in } \\
\text { circular tube with static built-in } \\
\text { twisted tape at the same condition. }\end{array}$ \\
\hline $\begin{array}{l}\text { Zhao et al. } \\
(2019)\end{array}$ & $\begin{array}{l}\text { CPU heat sink } \\
\text { with } \\
\text { rectangular } \\
\text { grooves and } \\
\text { cylindrical } \\
\text { bugles }\end{array}$ & $\begin{array}{l}\text { For rectangular grooves structure, } \\
\text { high exergy efficiency is sensitive } \\
\text { to large depth groove }(\mathrm{H}=2 \mathrm{~mm}) \text {, } \\
\text { small } \operatorname{Re}(\operatorname{Re}<545) \text { and small } \\
\text { nanoparticle }(\omega=0.1 \%) \text {. For } \\
\text { cylindrical bulges structure, high } \\
\text { exergy efficiency is sensitive to } \\
\text { aligned arrangement, small } \operatorname{Re}(\operatorname{Re} \\
<642) \text {. }\end{array}$ \\
\hline
\end{tabular}

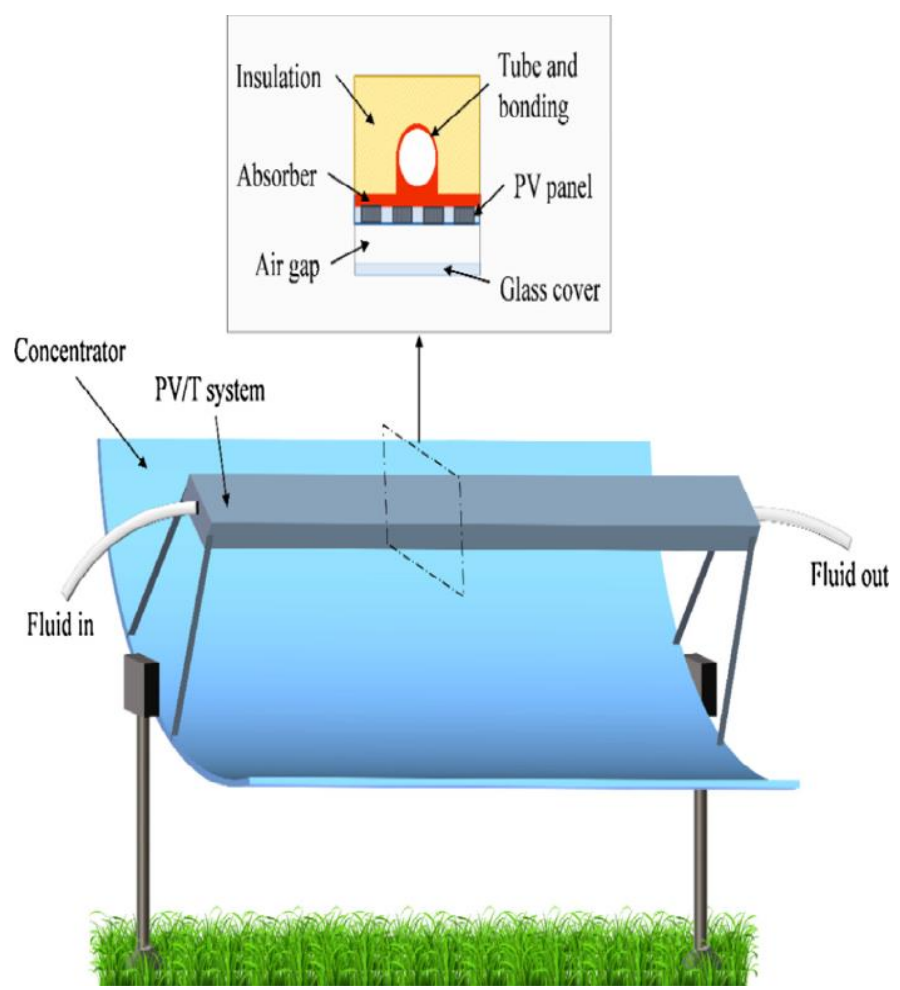

Fig. 11 Linear parabolic trough CPV/T (Yazdanifard et al. 2017)

\subsection{Exergy Analysis of $\mathrm{ZnO}$ based nanofluids flow through conduits}

Kumar et al. (2016) performed experimental work for detailed energetic and exergetic behaviour of $\mathrm{PHE}$ for $\mathrm{ZnO}$ /water nanofluid at varying particle volume concentrations ranges from $0.5 \%$ to $2.0 \%$, at different chevron angles $\beta=30^{\circ} / 30^{\circ}, 30^{\circ} / 60^{\circ}$ and $60^{\circ} / 60^{\circ}$ of the plate. Their outcomes showed that when particle volume concentration reaches 1.0 vol. \%, performance parameters exhibits optimum response. This optimum concentration corresponds to maximum heat transfer rate for all chevron angles in PHE.

Sardarabadi et al. (2017) analysis designing and fabricating two PVT and PVT/PCM systems, the positive effects of using these collectors as cooling systems for a photovoltaic module and investigate it experimentally. The thermal and electrical outputs of the systems as the critical parameters are compared with each other and with those of a conventional similar photovoltaic module as the reference system. Integrating the fluid-based collector of the PVT system with a PCM medium is considered as a new approach that can improve the system performance. The average thermal energy output of the PCM/waterbased collector is increment by $42 \%$ in comparison with the case of the water-based collector without a PCM medium. This value is about $48 \%$ for the case of PCM/nanofluid based collector in comparison with the case of the nanofluid based collector. From the exergy analysis outcomes, it is found that in the PVT fluid/nanofluid based collector system with the PCM medium, the overall exergy efficiency of the system is increment more than $23 \%$, in comparison with a conventional PV system.

\subsection{Previous investigation on exergy analysis of Graphene based nanofluid flow through conduits}

Esfahani and Languri (2017) organized graphene oxide in-house and used for nanofluid development and characterization. The graphene oxide was organized by oxidizing purified natural flake graphite via the modified Hummers method. The 0.01 and 0.1 wt. $\%$ graphene oxide NFs showed about $9 \%$ and $20 \%$ greater thermal conductivity compared to DI water at $25^{\circ} \mathrm{C}$, respectively. Different parameters such as effect of NFs concentrations, temperatures and flow rates of exergy destruction was examined experimentally. Comparing the exergy loss of graphene oxide NFs to DI water showed that DI water caused $22 \%$ and $109 \%$ greater exergy losses when compared to NFs at 0.01 and 0.1 wt. \% concentrations in laminar conditions, respectively.

Bahiraei et al. (2018) examined second law behaviour including entropy generation, exergy destruction, and second law efficiency for flow a novel nanofluid containing graphene-silver nanocomposite in a micro heat exchanger. A low exergy destruction happens in the wall due to the small temperature gradient in it. In comparison with the contribution of friction, rise of the Re intensifies the contribution of heat transfer to the exergy destruction, while rise of the concentration decreases it. The second law efficiency reduces by increasing either Re or concentration. Nazari et al. (2018) examined effects of applying graphene oxide nanofluid in thermal performance of a PHP are examined. Graphene oxide nanofluid in four concentrations $(0.25 \mathrm{~g} / \mathrm{lit}$, $0.5 \mathrm{~g} / \mathrm{lit}, 1 \mathrm{~g} / \mathrm{lit}$, and $1.5 \mathrm{~g} / \mathrm{lit}$ ) were used as working fluid in the PHP. Their outcomes are showed that the increasing concentration worsen thermal performance of the PHP which is attributed to rise in dynamic viscosity of working fluid.

\subsection{Exergy Analysis of Hybrid based nanofluid flow through conduits}

Ahammed et al. (2016) experimentally examined entropy generation analysis and heat transfer behaviour of alumina, graphene, and hybrid nanofluids in a multiport minichannel heat exchanger coupled with a 
thermoelectric cooler. Total entropy generation in the minichannel heat exchanger decreases by $31.86 \%$ with for graphene-water nanofluid; whereas it is only $19.6 \%$ and $6.15 \%$ for hybrid and alumina nanofluids respectively. The graphene-water nanofluid makes an enhancement of $88.62 \%$ in the convective heat transfer coefficient; whereas it is $63.13 \%$ and $31.89 \%$ for hybrid and alumina nanofluids respectively.

Bhattad et al. (2018) focused on the energetic and exergetic performance of counter flow plate heat exchanger with corrugation using hybrid nanofluid has been done for the milk chilling application. They observed that the performance index and irreversibility distribution ratio decrease with the nanofluid flow rate due to rise in pressure drop and pumping power. For the examined ranges, a maximum enhancement of $9.4 \%$ and $1.6 \%$ have been found in the heat transfer coefficient and heat transfer rate, respectively, for the PG based alumina silver hybrid nanofluid in comparison to the base fluid.

Maddah et al. (2018) investigation is concentrated on the advantages of passive techniques utilization in exergy efficiency of a double pipe heat exchanger. Their analysis showed that applying nanofluids and twisted tapes boost up the exergy efficiency in comparison to utilizing conventional water as a heat transfer fluid. Moreover, increasing the nanoparticles volume concentration, uplifting the $\mathrm{Re}$, reduction in twist ratio, all together can significantly raise up the exergy efficiency.

\subsection{1 $\mathrm{Ag}-\mathrm{SiO} \mathrm{O}_{2}$ based nanofluid}

Crisostomo et al. (2017) developed a detailed optical and heat losses model which allowed for the estimation of the electric and thermal outputs in addition to the heat loss break-down under different testing conditions used in concentrating PV/T collectors. This theoretical heat losses analysis revealed that by insulating the thermal receiver with a vacuum layer could lead to a reduction of $40 \%$ or $50 \%$ of the total heat loss.

\subsubsection{MgO based nanofluid}

Verma et al. (2016) experimentally observed the impact of mass flow rate and particle volume fraction on the efficiency of the collector. The finding reveals that a use of $\mathrm{MgO}$ nanofluid rises the efficiency of solar collector in comparison with water as working fluid by $9.34 \%$ for $0.75 \%$ particle volume fraction. Exergetic efficiency enhanced by $32.23 \%$ compare to water.

\subsubsection{SWCNTs based nanofluid}

Said, Saidur et al. (2014) focuses on analysis of thermal performance of using SWCNTs nanofluids as an absorbing medium in a flat plate solar collector and compared with other oxide based nanofluids. Second law of thermodynamics is used to investigate the performance of a solar collector operated with various nanofluids. Analytical outcomes revealed that SWCNT nanofluid could reduce the entropy generation by $4.34 \%$ and enhance the heat transfer coefficient by $15.33 \%$ theoretically compared to water as an absorbing fluid. With greater volume fraction of nanoparticles in fluids, greater heat transfer can be achieved.

\subsubsection{MWCNT Nanofluid}

Fayaz et al. (2018) present both numerically and experimentally performance evaluation and comparison of a PVT system operated by water and MWCNT-water nanofluid. FEM based software COMSOL Multiphysics has performed the numerical simulation. Their analysis showed that MWCNT-water provides significant advantages regarding thermal energy as well as electrical power, which makes the solar systems more efficient and compact.

\section{COMPARATIVE ANALYSIS}

\subsection{Comparison of $\mathrm{Al}_{2} \mathrm{O}_{3}$ and $\mathrm{CuO}$ nanofluids}

Ebrahimi et al. (2016) numerically examined heat transfer and singlephase laminar flow structures in a three-dimensional microchannel equipped with longitudinal vortex generators. Water- $\mathrm{Al}_{2} \mathrm{O}_{3}$ and water$\mathrm{CuO}$ nanofluids with different nanoparticle volume-fractions and sizes were compared to pure-water as working fluids. In addition, nanofluids with greater nanoparticle concentrations although again cost greater pressure drop, result in greater heat transfer enhancement. Khairul et al. (2017) analysed $\mathrm{Al}_{2} \mathrm{O}_{3} / \mathrm{DI}$-water and $\mathrm{CuO} / \mathrm{DI}$-water nanofluids with three different nanoparticles weight concentrations. Both the $\mathrm{Al}_{2} \mathrm{O}_{3} / \mathrm{DI}-$ water and $\mathrm{CuO} / \mathrm{DI}$-water nanofluids showed a noticeable rise in heat transfer coefficient in comparison to the DI-water for all flow regimes (laminar, transitional, and turbulent). Their outcomes showed that the friction factor was decreased as either the Re as well as weight fraction of nanoparticles in the nanofluids increment.

\subsection{Comparison of $\mathrm{CeO}_{2} /$ water and $\mathrm{ZnO} /$ water nanofluids}

Kumar et al. (2017) focused on experimental analysis of using $\mathrm{ZnO}$ /water nanofluid over $\mathrm{CeO}_{2} /$ water nanofluid and water in a PHE. The temperatures of hot fluid (water) and cold fluid (water/nanofluids) at inlet are fixed at $50^{\circ} \mathrm{C}$ and $25^{\circ} \mathrm{C}$ respectively. Their outcomes showed that the outcomes reveal that, $\mathrm{ZnO} /$ water nanofluid could reduce the exergy loss $5.81 \%, 3.57 \%, 4.39 \%$ and $6.43 \%$ for entire range of volume flow rates compared to $\mathrm{CeO}_{2} /$ water nanofluid. Overall performances of $\mathrm{ZnO} /$ water nanofluid is better than water and $\mathrm{CeO}_{2}$ /water nanofluid for all operating conditions.

\subsection{Comparison of $\mathrm{TiO}_{2}$ and $\mathrm{Al}_{2} \mathrm{O}_{3}$ nanofluids}

Mahian et al. (2012) applied the Second Law of thermodynamics to analysis the effect of using nanofluids on entropy generation between two concentric rotating cylinders with isoflux boundary conditions. Their outcomes showed that the entropy generation decreases with rises of volume fraction of nanoparticles where the contribution of heat transfer to entropy generation is dominant in the annulus. The outcomes show that $\mathrm{TiO}_{2}$ /water nanofluid is more suitable than $\mathrm{Al}_{2} \mathrm{O}_{3}$-EG nanofluid to use as the working fluid at low Brinkman numbers. Table. 5 shows the previous investigation on different nanofluids flow through conduits.

Table 5 Previous investigation on different nanofluids flow through conduits.

\begin{tabular}{|l|l|l|l|}
\hline \multicolumn{1}{|c|}{ Author (s) } & Nanofluid & \multicolumn{1}{|c|}{$\begin{array}{c}\text { Type of } \\
\text { channel }\end{array}$} & \multicolumn{1}{c|}{ Conclusion } \\
\hline $\begin{array}{l}\text { Crisostomo } \\
\text { et al. }\end{array}$ & $\mathrm{Ag}-\mathrm{SiO}_{2}$ & $\begin{array}{l}\text { Hybrid PV/T } \\
\text { collector }\end{array}$ & $\begin{array}{l}\text { The two most } \\
\text { concentrated NFs } \\
\text { acting as selective } \\
\text { absorbing fluids in } \\
\text { the experimental set- } \\
\text { up could deliver 9\% } \\
\text { more value than the } \\
\text { same PV cell array } \\
\text { illuminated with the } \\
\text { full concentrated } \\
\text { solar spectrum. }\end{array}$ \\
\hline $\begin{array}{l}\text { Verma et } \\
\text { al. (2016) }\end{array}$ & $\mathrm{MgO}$ & Flat plate solar \\
collector & $\begin{array}{l}\text { Economically we can } \\
\text { make compact } \\
\text { collector by reducing } \\
\text { surface area about } \\
12.5 \% \text { when using } \\
\text { nanofluid compare to } \\
\text { conventional fluid }\end{array}$ \\
\hline
\end{tabular}




\begin{tabular}{|c|c|c|c|}
\hline & & & water. \\
\hline $\begin{array}{l}\text { Fayaz et al. } \\
(2018)\end{array}$ & $\begin{array}{l}\text { MWCNT } \\
\text { Nanofluid }\end{array}$ & PVT system & $\begin{array}{l}\begin{array}{l}\text { Use of } \\
\text { MWater } \\
\text { significant } \\
\text { spovides }\end{array} \\
\text { advantages regarding } \\
\text { thermal energy as } \\
\text { well as electrical } \\
\text { power, which makes } \\
\text { the solar systems } \\
\text { more efficient and } \\
\text { compact. }\end{array}$ \\
\hline $\begin{array}{l}\text { Bahiraei } \\
\text { and } \\
\text { Heshmatian } \\
(2017)\end{array}$ & $\begin{array}{l}\text { Novel } \\
\text { Biological } \\
\text { Nanofluid } \\
\mathrm{s}\end{array}$ & $\begin{array}{l}\text { Liquid block } \\
\text { heat sink }\end{array}$ & $\begin{array}{l}\text { Irreversibility in the } \\
\text { whole liquid block } \\
\text { decreases by } \\
\text { increasing either } \\
\text { concentration or Re, } \\
\text { which is a positive } \\
\text { result based on } \\
\text { second law of } \\
\text { thermodynamics. }\end{array}$ \\
\hline $\begin{array}{l}\text { Al-Waeli et } \\
\text { al. (2017) }\end{array}$ & SiC-PCM & $\begin{array}{l}\text { Nano based } \\
\text { photovoltaic } \\
\text { thermal } \\
\text { system }\end{array}$ & $\begin{array}{l}\text { The operation of a } \\
\text { PV/T system using } \\
\text { nano-SiC-PCM and } \\
\text { nanofluids improves } \\
\text { the thermal and } \\
\text { electrical energy and } \\
\text { rises the overall } \\
\text { energy of the system } \\
\text { more than any PV/T } \\
\text { system. }\end{array}$ \\
\hline $\begin{array}{l}\text { Said et al. } \\
\text { (2014) }\end{array}$ & $\begin{array}{l}\text { SWCNT } \\
\text { Nanofluid } \\
\mathrm{s}\end{array}$ & $\begin{array}{l}\text { Conventional } \\
\text { flat plate solar } \\
\text { collector }\end{array}$ & $\begin{array}{l}\text { It has been found that } \\
\text { SWCNTs based } \\
\text { nanofluids have } \\
\text { better thermal } \\
\text { properties and this } \\
\text { consequently led to } \\
\text { improved thermal } \\
\text { and exergetic } \\
\text { efficiencies compared } \\
\text { to the metal oxide } \\
\text { nanofluids. }\end{array}$ \\
\hline $\begin{array}{l}\text { Sardarabadi } \\
\text { et } \quad \text { al. } \\
(2017)\end{array}$ & $\begin{array}{l}\mathrm{ZnO} / \\
\text { water } \\
\text { nanofluid }\end{array}$ & $\begin{array}{l}\text { Photovoltaic } \\
\text { thermal } \\
\text { systems }\end{array}$ & $\begin{array}{l}\text { The overall exergy } \\
\text { efficiency of the } \\
\text { system in the PVT } \\
\text { fluid/nanofluid based } \\
\text { collector system with } \\
\text { the PCM medium, is } \\
\text { increment more than } \\
23 \% \text {, in comparison } \\
\text { with a conventional } \\
\text { PV system. }\end{array}$ \\
\hline $\begin{array}{l}\text { Kumar et } \\
\text { al. }(2017)\end{array}$ & $\begin{array}{l}\text { Comparis } \\
\text { on of } \\
\mathrm{CeO}_{2-} \\
\text { water } \\
\mathrm{Zno} / \text { water } \\
\text { nanofluids }\end{array}$ & $\begin{array}{l}\text { Plate heat } \\
\text { exchanger }\end{array}$ & $\begin{array}{l}\text { Overall performances } \\
\text { of } \mathrm{ZnO} / \text { water } \\
\text { nanofluid is better } \\
\text { than water and } \\
\mathrm{CeO}_{2} / \text { water } \\
\text { nanofluid for all } \\
\text { operating conditions } \\
\text { being considered. }\end{array}$ \\
\hline $\begin{array}{l}\text { Mahian et } \\
\text { al. (2012) }\end{array}$ & $\begin{array}{l}\text { Comparis } \\
\text { on of } \mathrm{TiO}_{2} \\
\text { and } \mathrm{Al}_{2} \mathrm{O}_{3} \\
\text { nanofluids }\end{array}$ & $\begin{array}{l}\text { Co-rotating } \\
\text { cylinders }\end{array}$ & $\begin{array}{l}\mathrm{TiO}_{2} / \text { Water nanofluid } \\
\text { is more suitable than } \\
\mathrm{Al}_{2} \mathrm{O}_{3} / \mathrm{EG} \text { nanofluid } \\
\text { to use as the working } \\
\text { fluid at low } \\
\text { Brinkman numbers. }\end{array}$ \\
\hline Ebrahimi et & Comparis & Micro & $\mathrm{CuO} / \mathrm{DI}$-water \\
\hline
\end{tabular}

\begin{tabular}{|l|l|l|l|}
\hline $\begin{array}{l}\text { al. (2016), } \\
\text { Khairul et } \\
\text { al. (2017) } \\
\text { and Allouhi } \\
\text { et al. } \\
(2018)\end{array}$ & $\begin{array}{l}\text { on } \\
\mathrm{Al}_{2} \mathrm{O}_{3} \\
\text { and } \mathrm{CuO} \\
\text { nanofluids }\end{array}$ & $\begin{array}{l}\text { channels, } \\
\text { parabolic } \\
\text { trough } \\
\text { collector }\end{array}$ & $\begin{array}{l}\text { nanofluids has the } \\
\text { highest energy } \\
\text { efficiency and heat } \\
\text { transfer coefficient, } \\
\text { as well as lowest } \\
\text { friction factor and } \\
\text { exergy loss. The peak } \\
\text { exergy efficiency is } \\
\text { attained by the CuO } \\
\text { based nanofluid and } \\
\text { is about 9.05\%. }\end{array}$ \\
\hline
\end{tabular}

Fig.12 represents the comparative analysis of entropy generation ratio vs volume fraction with various nanoparticles such as $\mathrm{Al}_{2} \mathrm{O}_{3}-\mathrm{EG}$, $\mathrm{Al}_{2} \mathrm{O}_{3}-\mathrm{H}_{2} \mathrm{O}, \mathrm{Cu}-\mathrm{EG}$ and $\mathrm{Cu}-\mathrm{H}_{2} \mathrm{O}$. It can be observed that the $\mathrm{Al}_{2} \mathrm{O}_{3}-\mathrm{EG}$ based nanolfluid flow through conduits is better entropy generation as compared other based nanofluid. Fig.13 signifies the comparative analysis of entropy generation ratio vs Re with various values of volume fraction such as $\phi=0.01, \phi=0.02, \phi=0.03$ and $\phi=0.04$. The experimental outcomes showed that the value of $\phi=0.01$ is greater entropy generation ratio as compared other values of volume fraction such as $\phi=0.02, \phi=0.03$ and $\phi=0.04$.

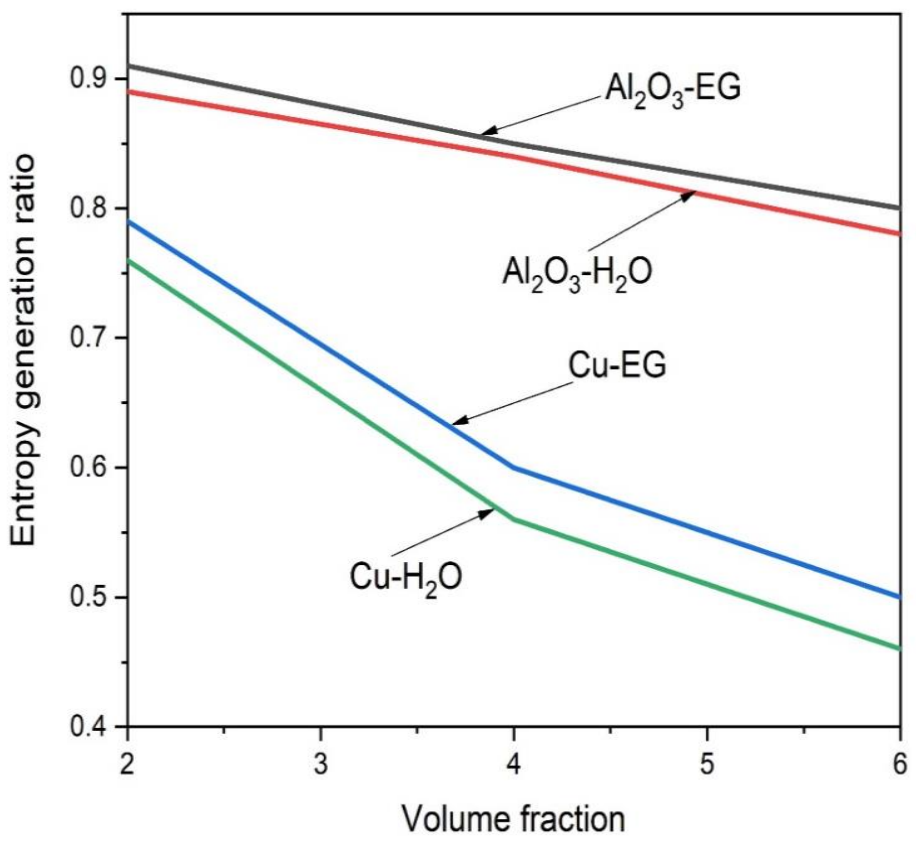

Fig. 12 Comparison entropy generation ratio vs volume fraction with various nanofluids (Sohel et al., 2013)

Fig.14 signifies the comparative analysis of exergetic efficiency vs volume flow rate with various nanofluids such as $\mathrm{ZnO}-\mathrm{H}_{2} \mathrm{O}$, $\mathrm{CeO}_{2}-\mathrm{H}_{2} \mathrm{O}$ and pure water with fixed value of nanoparticle concentration of $0.5 \%$. The experimental outcomes showed that with $\mathrm{ZnO}-\mathrm{H}_{2} \mathrm{O}$ based nanofluid flow through conduits greater exergetic efficiency as compared other nanofluids and pure water. Fig.15 signifies the comparative analysis of exergy vs $\mathrm{Re}$ with various values of volume fraction such as $\phi=0(\mathrm{Vol} \%), \phi=0.01(\mathrm{Vol} \%), \phi=0.03(\mathrm{Vol} \%)$, $\phi=0.3(\mathrm{Vol} \%)$ and $\phi=0.5(\mathrm{Vol} \%)$. The experimental outcomes showed that the value of $\phi=0(\mathrm{Vol} \%)$, is greater value of exergy as compared other values of volume fraction such. Fig.16 signifies the comparative analysis of outlet exergy vs flow rate with $\mathrm{TiO}_{2}-\mathrm{H}_{2} \mathrm{O}$ and pure water. The experimental outcomes showed that $\mathrm{TiO}_{2}-\mathrm{H}_{2} \mathrm{O}$ based nanofluid flow through conduits is greater value of outlet exergy as compared with pure water. 


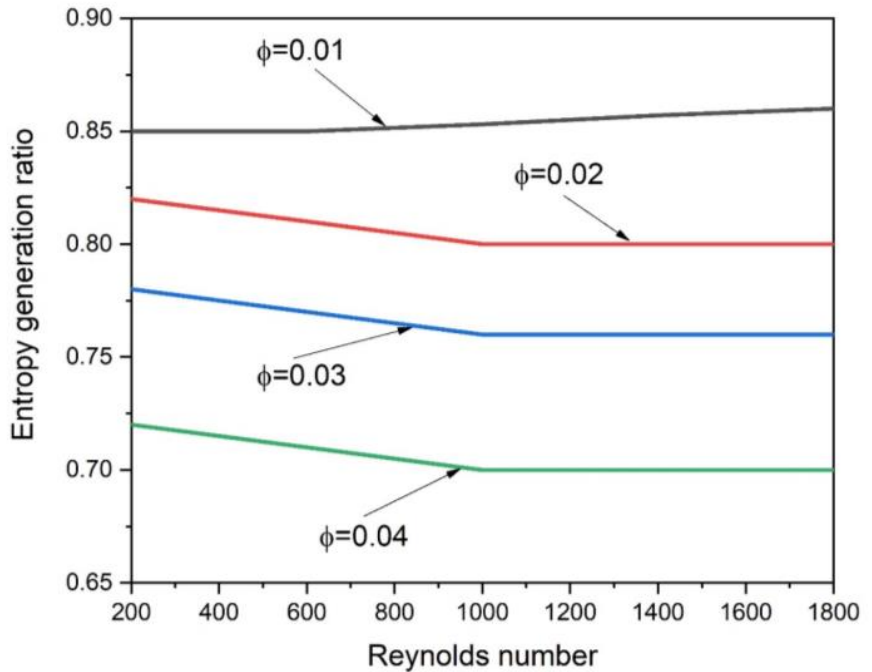

Fig. 13 Comparison entropy generation ratio vs Re with various nanoparticle concentration (Moghaddami et al., 2012)

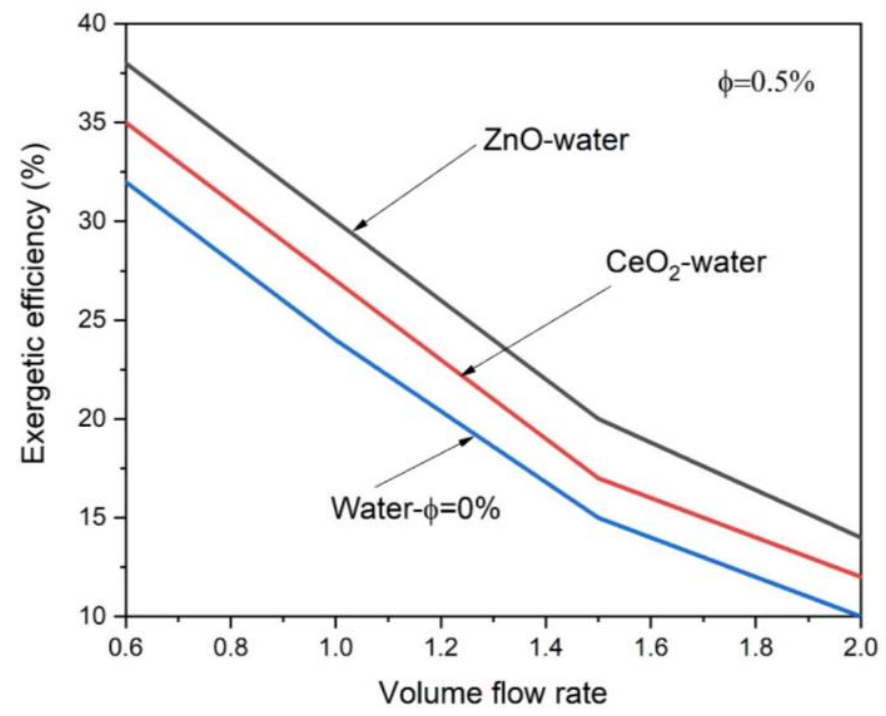

Fig. 14 Comparison exergetic efficiency vs volume flow rate with different nanofluids and pure water (Kumar et al., 2017)

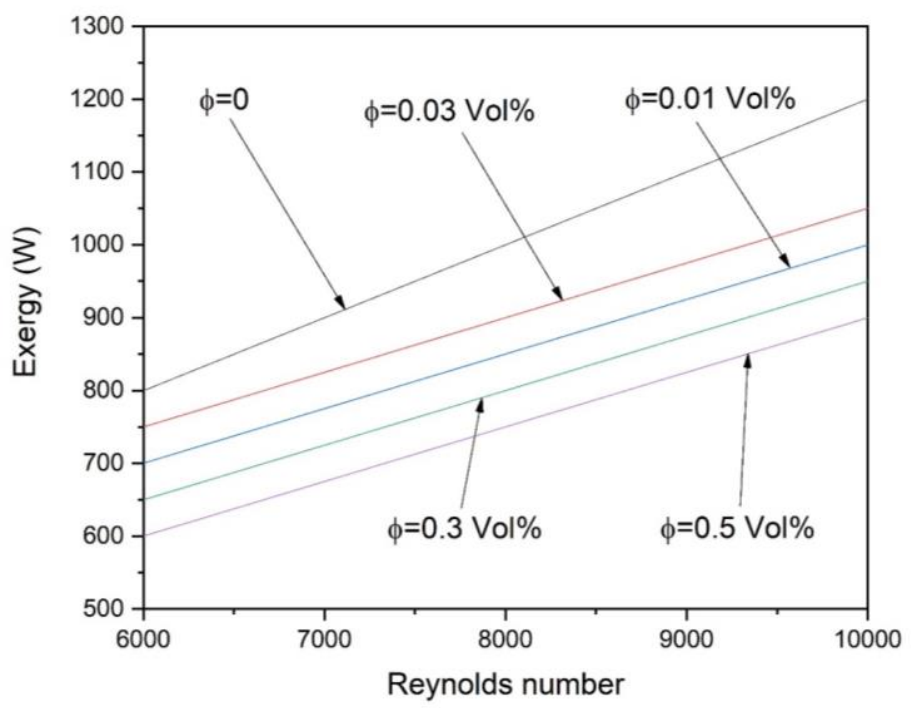

Fig. 15 Comparison exergy vs Re with different nanoparticle concentration (Abdollahi-Moghaddam et al., 2018)

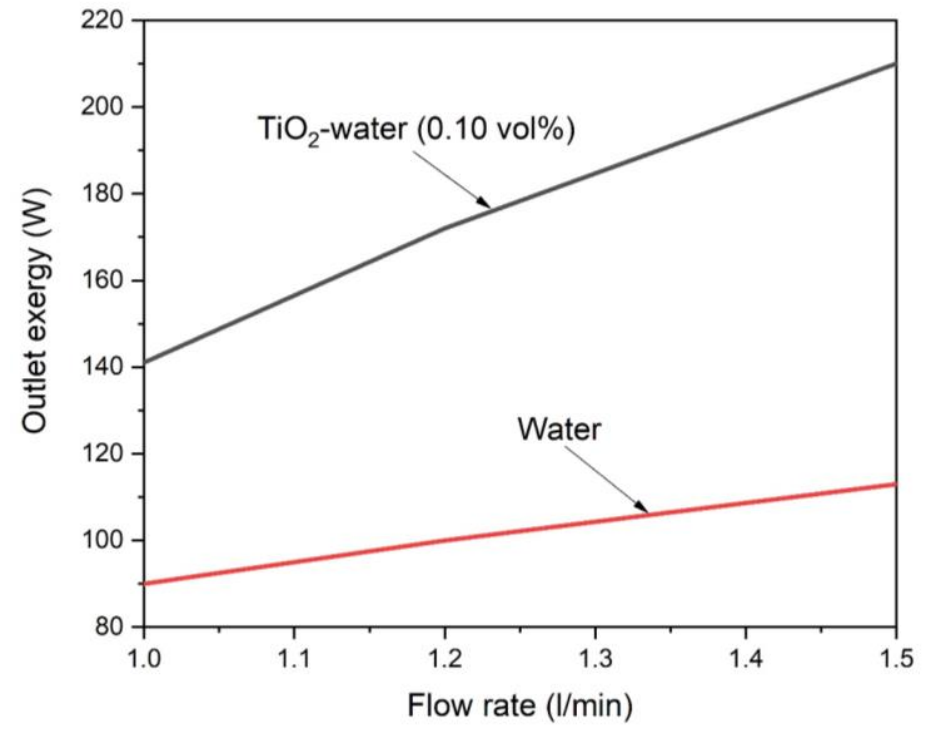

Fig. 16 Comparison outlet exergy vs flow rate with Titanium oxide/water nanofluids with pure water (Khaleduzzaman et al., 2016)

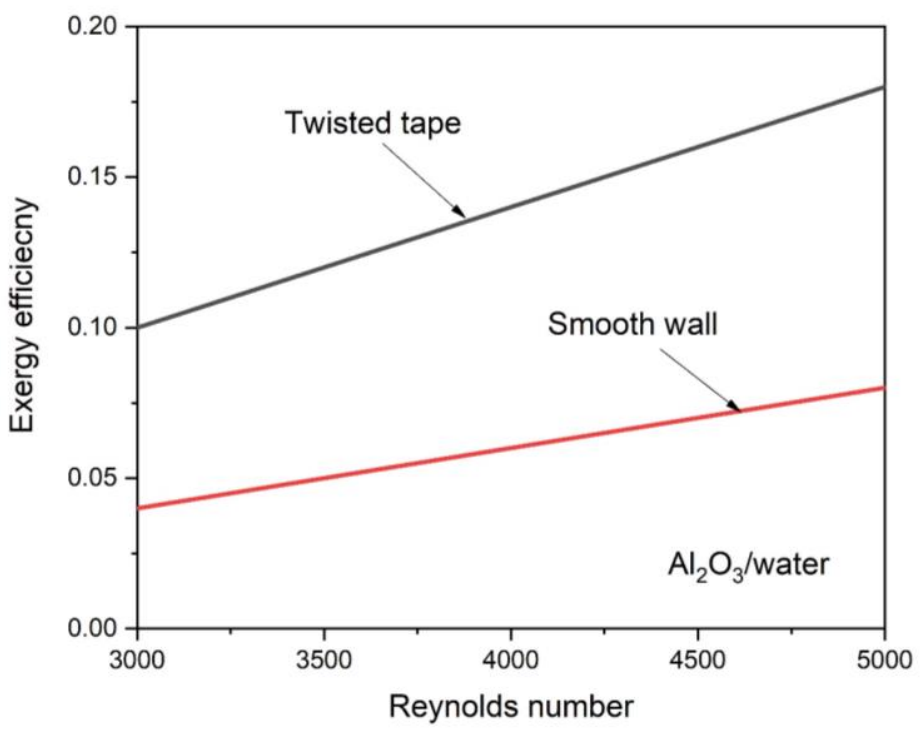

Fig. 17 Comparative analysis exergy efficiency vs Re with twisted tape and smooth wall channel (Source: As per literature review)

Fig.17 represents the comparative analysis of exergy efficiency vs Re with twisted tape inserts and pure water for $\mathrm{Al}_{2} \mathrm{O}_{3}-\mathrm{H}_{2} \mathrm{O}$ based nanofluid through conduits. The experimental outcomes showed that the value of exergy efficiency is greater for twisted tape inserts as compared without twisted tape inserts surface.

\section{CONCLUSIONS}

In this article a review of exergy analysis of various nanofluids flow through conduits is presented. On the basis of the review of literature and comparative study of exergy analysis with nanofluid flow through conduits, the conclusions can be summarizes as follows:

- The exergetic and heat transfer performance of $\mathrm{ZnO} /$ water nanofluid are better than $\mathrm{CeO}_{2}$ /water nanofluid and water whereas $\mathrm{TiO}_{2}$ /Water nanofluid is more suitable than $\mathrm{Al}_{2} \mathrm{O}_{3}$ /EG nanofluid to use as the working fluid at low Brinkman numbers.

- $\quad$ SWCNTs based nanofluids have better thermal properties and this consequently led to improved thermal and exergetic 
efficiencies compared to the metal oxide nanofluids. This, on the other hand, also raised convection heat transfer coefficient compared to the conventional fluids at the same given Re. SWCNT nanofluid could reduce the entropy generation by $4.34 \%$ and enhance the heat transfer coefficient by $15.33 \%$ theoretically compared to water as an absorbing fluid.

- The rise of entropy generation induced by the rise of nanoparticle volume fraction is attributed to the rise of both the thermal conductivity and viscosity of nanofluid which causes augmentation in the heat transfer and fluid friction irreversibility, respectively. On the other hand, the first-law analysis shows that the heat transfer coefficient decreases with nanoparticle volume fraction largely in the laminar regime of nanofluid flow in microchannel when the viscous dissipation effect is taken into account.

- The optimum Re and the corresponding minimum entropy generation number is found for different examined nanoparticle concentrations revealing that adding nanoparticles to water decreases the optimum Res while it rises the minimum total entropy generation.

- The entropy generation of nanofluids has been more than that of base fluids like water/EG for both laminar as well as turbulent flow at all values of Re.

- The outcomes showed that with increasing concentration ratio, the PV and outlet temperatures rise in both flow regimes. The total energy efficiency in turbulent flow rises, while the total energy efficiency in laminar flow first rises, and then decreases at a particular concentration ratio. The total exergy efficiency rises in laminar flow, whereas in turbulent flow, it initially rises up to an optimum concentration ratio and then decreases.

- Investigation on tube geometries showed that, with increasing pipe length, the PV and outlet water temperatures rise in both laminar and turbulent regimes. The total energy efficiency decreases, but the total exergy efficiency rises in both flow regimes. In addition, increasing the pipe diameter has a negligible effect on energy and exergy efficiencies in the laminar flow, whereas the total energy and exergy efficiencies decrease with increasing pipe diameter in the turbulent regime. Therefore, outcomes of this investigation revealed the importance of optimizing the structural and geometrical parameters to achieve desired system performance based on the flow regime type.

- The outcomes for the surface temperature measurement showed that using a fluid as coolant for the PVT system, can reduce the cell temperature by about 10 degrees. The cell temperature reduction of the PVT fluid/nanofluid coolant system with a PCM medium is more than 16 degrees compared to that of the reference system in the same condition. Also, it is concluded that for the PCM/nanofluid based collector system, the average electrical output is increment by about $13 \%$ in comparison with the conventional PV module.

- The entropy generation decreases with rises of volume fraction of nanoparticles where the contribution of heat transfer to entropy generation is dominant in the annulus.

\section{NOMENCLATURE}

$\begin{array}{ll}\mathrm{Re} & \text { Reynolds number } \\ \mathrm{Nu} & \text { Nusselt number } \\ \mathrm{Al}_{2} \mathrm{O}_{3} & \text { Aluminium oxide } \\ \mathrm{TiO}_{2} & \text { Titanium oxide } \\ \mathrm{CuO} & \text { Copper oxide } \\ \mathrm{MgO} & \text { Magnesium oxide } \\ \mathrm{ZnO} & \text { Zinc oxide }\end{array}$

Subscripts

EG

SWCNT

$M W C N T$

$P V T$ 's

$P C M$

$N F S$

Ethylene glycol

Single-walled carbon nanotubes

Multi- walled carbon nanotubes

Photo voltaic thermal system

Collector-phased change material

Nanofluids

\section{REFERENCES}

Suzuki, H. O., and Oshida, I., (1987), "Application of Exergy Concept to the Analysis of Optimum Operating Conditions of Solar Heat Collectors," Journal of Solar Energy Engineering, 109(4),337-342. https://doi.org/10.1115/1.3268226

Abdollahi-Moghaddam M., Motahari, K., and Rezaei, A., (2018), "Performance behaviour of low concentrations of $\mathrm{CuO}$ /water nanofluids flowing through horizontal tube for energy efficiency purposes; an experimental analysis and ANN modeling," Journal of Molecular Liquids ,271, 342-352.

https://doi.org/10.1016/j.molliq.2018.08.149

Ahammed N., Asirvatham, L. G., and Wongwises, S., (2016), "Entropy generation analysis of graphene-alumina hybrid nanofluid in multiport minichannel heat exchanger coupled with thermoelectric cooler," International Journal of Heat and Mass Transfer ,103, 1084-1097. https://doi.org/10.1016/j.ijheatmasstransfer.2016.07.070

Ahmed, A., Baig, H., Sundaram, S., and Mallick, T. K., (2019), "Use of Nanofluids in Solar PV/Thermal Systems," International Journal of Photoenergy ,2019, 1-17.

https://doi.org /10.1155/2019/8039129

Ahmad Q. I., Mohd. Yahya, S., Saad Bin Arif, M., and Jamil, A., (2020), "Nanofluids application in hybrid Photovoltaic Thermal System for Performance Enhancement: A review," AIMS Energy, 8(3), 365393.

https://doi.org /10.3934/energy.2020.3.365

Al-Waeli, A. H. A., Sopian, K., Chaichan, M. T., Kazem, H. A., Ibrahim, A., Mat, S., and Ruslan, M. H., (2017), "Evaluation of the nanofluid and nano-PCM based photovoltaic thermal (PVT) system: An experimental analysis." Energy Conversion and Management ,151, 693708.

https://doi.org/10.1016/j.enconman.2017.09.032

Allouhi, A., Benzakour, Amine, M., Saidur, R., Kousksou, T., and Jamil, A., (2018), "Energy and exergy analyses of a parabolic trough collector operated with nanofluids for medium and high temperature applications." Energy Conversion and Management , 155, 201-217. https://doi.org/10.1016/j.enconman.2017.10.059

Armaghani, T., Kasaeipoor, A., Alavi, N., and Rashidi, M. M., (2016), "Numerical investigation of water-alumina nanofluid natural convection heat transfer and entropy generation in a baffled L-shaped cavity." Journal of Molecular Liquids ,223, 243-251. https://doi.org/10.1016/j.molliq.2016.07.103

Arora, S., Fekadu, G., and Subudhi, S., (2019), "Energy and Exergy Analysis of Marquise Shaped Channel Flat Plate Solar Collector Using A12O3-Water Nanofluid and Water," Journal of Solar Energy Engineering ,141(4), 041008. https://doi.org/10.1115/1.4042454

Bahiraei, M., and Heshmatian, S., (2017), "Application of a novel biological nanofluid in a liquid block heat sink for cooling of an electronic processor: Thermal performance and irreversibility considerations," Energy Conversion and Management ,149, 155-167. 


\section{$\underline{\text { https://doi.org/10.1016/j.enconman.2017.07.020 }}$}

Bahiraei, M., Jamshidmofid, M., Amani, M., and Barzegarian, R., (2018), "Investigating exergy destruction and entropy generation for flow of a new nanofluid containing graphene-silver nanocomposite in a micro heat exchanger considering viscous dissipation," Powder Technology, 336, 298-310.

https://doi.org/10.1016/j.powtec.2018.06.007

Bellos, E., Tzivanidis, C., and Tsimpoukis, D., (2018), "Thermal, hydraulic and exergetic evaluation of a parabolic trough collector operating with thermal oil and molten salt based nanofluids" Energy Conversion and Management ,156, 388-402.

https://doi.org/10.1016/j.enconman.2017.11.051

Bhattad, A., Sarkar, J., and Ghosh, P., (2018), "Energetic and Exergetic Performances of Plate Heat Exchanger Using Brine-Based Hybrid Nanofluid for Milk Chilling Application," Heat Transfer Engineering , $114,522-535$

https://doi.org/10.1080/01457632.2018.1546770

Chamkha, A. J., Rashad, A. M. , Mansour, M. A., Armaghani, T., and Ghalambaz, M., (2017), "Effects of heat sink and source and entropy generation on MHD mixed convection of a $\mathrm{Cu}$-water nanofluid in a liddriven square porous enclosure with partial slip," Physics of Fluids , 29(5).

https://doi.org/10.1063/1.4981911

Chein, R., and Huang, G., (2005), "Analysis of microchannel heat sink performance using nanofluids," Applied Thermal Engineering ,25(1718), 3104-3114.

https://doi.org/10.1016/j.applthermaleng.2005.03.008

Chen, C.-H., and Ding, C.-Y., (2011), "Analysis on the thermal behavior and cooling performance of a nanofluid-cooled microchannel heat sink," International Journal of Thermal Sciences ,50(3), 378-384. https://doi.org/10.1016/j.ijthermalsci.2010.04.020

Chen, C. o.-K., Chen, B.-S., and Liu, C.-C., (2014), "Heat transfer and entropy generation in fully-developed mixed convection nanofluid flow in vertical channel," International Journal of Heat and Mass Transfer, 79, $750-758$.

https://doi.org/10.1016/j.ijheatmasstransfer.2014.08.078

Choi, S. U. S., (2009), "Nanofluids: From Vision to Reality Through Research," Journal of Heat Transfer ,131(3), 033106.

$\underline{\text { https://doi.org/10.1115/1.3056479 }}$

Crisostomo, F., Hjerrild, N., Mesgari, S., Li, Q., and Taylor, R. A., (2017), "A hybrid PV/T collector using spectrally selective absorbing nanofluids," Applied Energy ,193, 1-14.

https://doi.org/10.1016/j.apenergy.2017.02.028

Das, S. K., Choi, S. U. S., and Patel, H. E., (2006), "Heat Transfer in Nanofluids-A Review," Heat Transfer Engineering ,27(10), 3-19. https://doi.org/10.1080/01457630600904593

Dincer, I., (2001), "Energy, Entropy and Exergy Concepts and Their Roles in Thermal Engineering," Entropy ,3(3), 116-149.

https://doi.org/10.3390/e3030116

Dincer, I., (2010), "Thermodynamics, Exergy and Environmental Impact," Energy Sources ,22(8), 723-732.

https://doi.org/10.1080/00908310050120272

Dutta, S.K., and Biswas, A.K., (2018), "Entropy Generation Due to Natural Convection with Non -Uniform Heating of Porous Quadrantal
Enclosure-a Numerical Study," Frontiers in Heat and Mass Transfer $, \mathbf{1 0}, 8$. https://doi.org/10.5098/hmt.10.8

Ebrahimi, A., Rikhtegar, F., Sabaghan, A., and Roohi, E., (2016), "Heat transfer and entropy generation in a microchannel with longitudinal vortex generators using nanofluids," Energy ,101, 190-201. https://doi.org/10.1016/j.energy.2016.01.102

Edalatpour, M., and Solano, J. P., (2017), "Thermal-hydraulic behaviour and exergy performance in tube-on-sheet flat plate solar collectors: Effects of nanofluids and mixed convection," International Journal of Thermal Sciences ,118, 397-409. https://doi.org/10.1016/j.ijthermalsci.2017.05.004

Enrico Sciubba, G. W., (2007), "A brief Commented History of Exergy From the Beginnings to 2004," Int. J. of Thermodynamics , 10, 1-26. https://doi.org/10.5541/ijot.184

Esfahani, M. R., and Languri, E. M., (2017), "Exergy analysis of a shell-and-tube heat exchanger using graphene oxide nanofluids," Experimental Thermal and Fluid Science ,83, 100-106. https://doi.org/10.1016/j.expthermflusci.2016.12.004

Farshad, S. A., and Sheikholeslami, M., (2019), "Nanofluid flow inside a solar collector utilizing twisted tape considering exergy and entropy analysis," Renewable Energy, 141, 246-258. https://doi.org/10.1016/j.renene.2019.04.007

Fayaz, H., Nasrin, R., Rahim, N. A., and Hasanuzzaman, M., (2018), "Energy and exergy analysis of the PVT system: Effect of nanofluid flow rate," Solar Energy, 169: 217-230. https://doi.org/10.1016/j.solener.2018.05.004

Gangadevi, R., Vinayagam, B. K., and Senthilraja, S., (2017), "Experimental investigations of hybrid PV/Spiral flow thermal collector system performance using Al2O3/water nanofluid," IOP Conference Series: Materials Science and Engineering ,197, 012041. https://doi.org/10.1088/1757-899X/197/1/012041

Hajialigol, N., Fattahi, A., Ahmadi, M. H., Qomi, M. E., and Kakoli, E., (2015), "MHD mixed convection and entropy generation in a 3-D microchannel using Al2O3-water nanofluid," Journal of the Taiwan Institute of Chemical Engineers ,46, 30-42. https://doi.org/10.1016/j.jtice.2014.09.002

Hassan, M., Sadri, R., Ahmadi, G., Dahari, M., Kazi, S., Safaei, M., and Sadeghinezhad, E., (2013), "Numerical Analysis of Entropy Generation in a Flowing Nanofluid Used in Micro- and Minichannels," Entropy 15(1), 144-155.

https://doi.org/10.3390/e15010144

Jedsadaratanachai, W., and Boonloia, A., (2018), "Numerical Predictions on Flow and Heat Transfer in Heat Exchanger Tube Equipped with Various Flow Attack Angles of Inclined-Wavy Surface," Frontiers in Heat and Mass Transfer ,11,10. https://doi.org/ 10.5098/hmt.11.10

Jie Li, C. K., (2010), "Computer simulation of Entropy Generation Analysis for Nanofluid Flow in Microchannels," Journal of Heat Transfer ,132(12), 122401. https://doi.org/10.1115/1.4002395

Khairul, M. A., Alim, M. A., Mahbubul, I. M., Saidur, R., Hepbasli, A., and Hossain, A., (2014), "Heat transfer performance and exergy analyses of a corrugated plate heat exchanger using metal oxide 
nanofluids," International Communications in Heat and Mass Transfer ,50, 8-14.

https://doi.org/10.1016/j.icheatmasstransfer.2013.11.006

Khairul, M. A., Doroodchi, E., Azizian, R., and Moghtaderi, B., (2017), "The influence of different flow regimes on heat transfer performance and exergy loss of Al2O3/DI-water and CuO/DI-water nanofluids," Applied Thermal Engineering ,122, 566-578.

https://doi.org/10.1016/j.applthermaleng.2017.05.035

Khaleduzzaman, S. S., Sohel, M. R., Mahbubul, I. M., Saidur, R., and Selvaraj, J., (2016), "Exergy and entropy generation analysis of TiO 2 water nanofluid flow through the water block as an electronics device," International Journal of Heat and Mass Transfer ,101, 104-111. https://doi.org/10.1016/j.ijheatmasstransfer.2016.05.026

Khorasanizadeh, H., Amani, J., and Nikfar, M., (2012), "Numerical investigation of $\mathrm{Cu}$-water nanofluid natural convection and entropy generation within a cavity with an embedded conductive baffle," Scientia Iranica ,19(6), 1996-2003.

https://doi.org/10.1016/j.scient.2012.07.018

Khoshvaght-Aliabadi, M., and Sahamiyan, M., (2016), "Performance of nanofluid flow in corrugated minichannels heat sink (CMCHS)," Energy Conversion and Management ,108, 297-308. https://doi.org/10.1016/j.enconman.2015.11.026

Kotas, T. J., (1980), "Exergy Concepts for Thermal Plant," Int j. Heat \& fluid flow ,2, 105-114.

https://doi.org/10.1016/0142-727X(80)90028-4

Kumar, V., Tiwari, A. K., and Ghosh, S. K., (2016), "Effect of chevron angle on heat transfer performance in plate heat exchanger using $\mathrm{ZnO}$ /water nanofluid," Energy Conversion and Management ,118, 142154.

https://doi.org/10.1016/j.enconman.2016.03.086

Kumar, V., Tiwari, A. K., and Ghosh, S. K., (2017), "Characterization and performance of nanofluids in plate heat exchanger," Materials Today: Proceedings ,4(2), 4070-4078.

https://doi.org/10.1016/j.matpr.2017.02.310

Leong, K. Y., Saidur, R., Mahlia, T. M. I., and Yau, Y. H., (2012), "Entropy generation analysis of nanofluid flow in a circular tube subjected to constant wall temperature," International Communications in Heat and Mass Transfer ,39(8), 1169-1175.

https://doi.org/10.1016/j.icheatmasstransfer.2012.06.009

Li, J., and Kleinstreuer, C., (2008), "Thermal performance of nanofluid flow in microchannels," International Journal of Heat and Fluid Flow, 29(4), 1221-1232.

https://doi.org/10.1016/j.ijheatfluidflow.2008.01.005

Li, Z., Khan, I., Shafee, A., Tlili, I., and Asifa, T., (2018), "Energy transfer of Jeffery-Hamel nanofluid flow between non-parallel walls using Maxwell-Garnetts (MG) and Brinkman models." Energy Reports ,4, 393-399.

https://doi.org/10.1016/j.egyr.2018.05.003

Moran, M. J. , E. S., (1994), "Exergy Analysis: Principles and Practice," Journal of Engineering for Gas Turbines and Power ,116(2), 285-290.

https://doi.org/10.1115/1.2906818

Maddah, H., Aghayari, R., Mirzaee, M., Ahmadi, M. H., Sadeghzadeh, M., and Chamkha, A. J., (2018), "Factorial experimental design for the thermal performance of a double pipe heat exchanger using Al2O3-
TiO2 hybrid nanofluid," International Communications in Heat and Mass Transfer ,97, 92-102.

https://doi.org/10.1016/j.icheatmasstransfer.2018.07.002

Mah, W. H., Hung, Y. M., and Guo, N., (2012), "Entropy generation of viscous dissipative nanofluid flow in microchannels," International Journal of Heat and Mass Transfer ,55(15-16), 4169-4182. https://doi.org/10.1016/j.ijheatmasstransfer.2012.03.058

Mahian, O., Kianifar, A., Sahin, A. Z., and Wongwises, S., (2014), "Entropy generation during Al 203 /water nanofluid flow in a solar collector: Effects of tube roughness, nanoparticle size, and different thermophysical models," International Journal of Heat and Mass Transfer ,78, 64-75.

https://doi.org/10.1016/j.ijheatmasstransfer.2014.06.051

Mahian, O., Mahmud, S., and Heris, S. Z., (2012), "Analysis of entropy generation between co-rotating cylinders using nanofluids." Energy, 44(1), 438-446.

https://doi.org/10.1016/j.energy.2012.06.009

Mahian, O., Mahmud, S., and Wongwises, S., (2013), "Entropy Generation Between Two Rotating Cylinders with Magnetohydrodynamic Flow Using Nanofluids," Journal of Thermophysics and Heat Transfer ,27(1), 161-169. https://doi.org/10.2514/1.T3908

Manca, O., Jaluria Y., and Poulikakos, D., (2010), "Heat Transfer in Nanofluids," Advances in Mechanical Engineering , 2010, Article ID 380826.

https://doi.org/10.1155/2010/380826

Manca, O., Nardini, S., and Ricci, D., (2012), "A numerical analysis of nanofluid forced convection in ribbed channels," Applied Thermal Engineering ,37, 280-292.

https://doi.org/10.1016/j.applthermaleng.2011.11.030

McGovern, J. A., (1990), "Exergy analysis-a different perspective on energy - Part 1 : the concept of exergy," Energy ,204, 253-262. https://doi.org/10.1243\%2FPIME_PROC_1990_204_034_02

Michael, J. J., and Iniyan, S., (2015), "Performance analysis of a copper sheet laminated photovoltaic thermal collector using copper oxide water nanofluid," Solar Energy ,119, 439-451.

https://doi.org/10.1016/i.solener.2015.06.028

Moghaddami, M., Shahidi, S., and Siavashi, M., (2012), "Entropy Generation Analysis of Nanofluid Flow in Turbulent and Laminar Regimes," Journal of Computational and Theoretical Nanoscience , 9(10), 1586-1595.

https://doi.org/10.1166/jetn.2012.2249

Nagarajan, P.K., Subramani, J., Suyambazhahan, S., and Sathyamurthy, R., (2014), "Nanofluids for Solar Collector Applications: A Review," Energy Procedia, 61, 2416-2434.

https://doi.org/ 10.1016/j.egypro.2014.12.017

Nazari, M. A., Ghasempour, R., Ahmadi, M. H., Heydarian, G., and Shafii, M. B., (2018), "Experimental investigation of graphene oxide nanofluid on heat transfer enhancement of pulsating heat pipe," International Communications in Heat and Mass Transfer ,91, 90-94. https://doi.org/10.1016/j.icheatmasstransfer.2017.12.006

Qi, C., Wang, G., Yan, Y., Mei, S., and Luo, T., (2018), "Effect of rotating twisted tape on thermo-hydraulic performances of nanofluids in heat-exchanger systems," Energy Conversion and Management ,166, 744-757. 


\section{$\underline{\text { https://doi.org/10.1016/j.enconman.2018.04.086 }}$}

Querol, E., Gonzalez-Regueral, B., and Perez-Benedito, J. L., (2013), Exergy Concept and Determination, Practical Approach to Exergy and Thermoeconomic Analyses of Industrial Processes, 9-28.

https://doi.org/ 10.1007/978-1-4471-4622-3

Rashidi, S., Akar, S., Bovand, M., and Ellahi, R., (2018), "Volume of fluid model to simulate the nanofluid flow and entropy generation in a single slope solar still," Renewable Energy ,115, 400-410. https://doi.org/10.1016/j.renene.2017.08.059

Ray, D. R., Das, D. K., and Vajjha, R. S., (2014), "Experimental and numerical investigations of nanofluids performance in a compact minichannel plate heat exchanger," International Journal of Heat and Mass Transfer ,71, 732-746.

https://doi.org/10.1016/j.ijheatmasstransfer.2013.12.072

Said, Z., Sabiha, M. A., Saidur, R., Hepbasli, A., Rahim, N. A., Mekhilef, S., and Ward, T. A., (2015), "Performance enhancement of a Flat Plate Solar collector using Titanium dioxide nanofluid and Polyethylene Glycol dispersant," Journal of Cleaner Production ,92, 343-353.

https://doi.org/10.1016/j.jclepro.2015.01.007

Said, Z., Saidur, R., and Rahim, N. A., (2016), "Energy and exergy analysis of a flat plate solar collector using different sizes of aluminium oxide based nanofluid," Journal of Cleaner Production ,133, 518-530. https://doi.org/10.1016/j.jclepro.2016.05.178

Said, Z., Saidur, R., Rahim, N. A., and Alim, M. A., (2014), "Analyses of exergy efficiency and pumping power for a conventional flat plate solar collector using SWCNTs based nanofluid," Energy and Buildings ,78, 1-9.

https://doi.org/10.1016/j.enbuild.2014.03.061

Said, Z., Saidur, R., Sabiha, M. A., Hepbasli, A., and Rahim, N. A., (2016), "Energy and exergy efficiency of a flat plate solar collector using pH treated $\mathrm{Al} 2 \mathrm{O} 3$ nanofluid," Journal of Cleaner Production ,112, 3915-3926.

https://doi.org/10.1016/j.jclepro.2015.07.115

Sardarabadi, M., Passandideh-Fard, M., Maghrebi, M.-J., and Ghazikhani, M., (2017), "Experimental analysis of using both $\mathrm{ZnO} /$ water nanofluid and phase change material (PCM) in photovoltaic thermal systems," Solar Energy Materials and Solar Cells ,161, 62-69. https://doi.org/10.1016/j.solmat.2016.11.032

Shabgard, H., and Faghri, A., (2019), "Exergy Analysis in Energy Systems: Fundamentals and Application," Frontiers in Heat and Mass Transfer ,12,9.

https://doi.org /10.5098/hmt.12.9

Shojaeizadeh, E., and Veysi, F., (2016), "Development of a correlation for parameter controlling using exergy efficiency optimization of an $\mathrm{Al}$ $2 \mathrm{O} 3$ /water nanofluid based flat-plate solar collector," Applied Thermal Engineering ,98, 1116-1129.

https://doi.org/10.1016/j.applthermaleng.2016.01.001

Shojaeizadeh, E., Veysi, F., and Kamandi, A., (2015), "Exergy efficiency investigation and optimization of an Al2O3-water nanofluid based Flat-plate solar collector," Energy and Buildings ,101, 12-23. https://doi.org/10.1016/j.enbuild.2015.04.048

Singh, P. K., Anoop, K. B., Sundararajan, T., and Das, S. K., (2010), "Entropy generation due to flow and heat transfer in nanofluids,"
International Journal of Heat and Mass Transfer ,53(21-22), 47574767.

https://doi.org/10.1016/j.ijheatmasstransfer.2010.06.016

Singh Y., Maithani, R., Kumar, S. , and Gholamalizadeh, E., Kumar, A., (2018), "Development of New Correlations for Nusselt Number and Friction Factor of TiO2/Water Based Nanofluid flow In V-Pattern Protrusion Ribbed Square Channel," Frontiers in Heat and Mass Transfer ,11,33.

https://doi.org /10.5098/hmt.11.33

Sohel, M. R., Saidur, R., Hassan, N. H., Elias, M. M., Khaleduzzaman, S. S., and Mahbubul, I. M., (2013), "Analysis of entropy generation using nanofluid flow through the circular microchannel and minichannel heat sink," International Communications in Heat and Mass Transfer ,46, 85-91.

https://doi.org/10.1016/j.icheatmasstransfer.2013.05.011

SUZUKI, A., (1988), "General Theory Of Exergy-Balance Analysis And Application To Solar Collectors," Energy ,13, 153-160.

https://doi.org/10.1016/0360-5442(88)90040-0

Ting,T.W.,and Ningqun Guo Y. M. H., (2013), "An analytical analysis of the viscous dissipation effect on entropy generation of forced convection of water-alumina nanofluid in a circular microchannel" Heat and Mass Transfer, MNHMT2013-22103, V001T02A009.

https://doi.org/10.1115/MNHMT2013-22103

Tsatsaronis, G., (2007), "Definitions and nomenclature in exergy analysis and exergoeconomics," Energy ,32(4), 249-253.

https://doi.org/10.1016/j.energy.2006.07.002

Valero, A., (2006), "Exergy accounting: Capabilities and drawbacks," Energy ,31(1), 164-180.

https://doi.org/10.1016/j.energy.2004.04.054

Verma, S. K., Tiwari, A. K., and Chauhan, D. S., (2016), "Performance augmentation in flat plate solar collector using $\mathrm{MgO} /$ water nanofluid," Energy Conversion and Management ,124, 607-617.

https://doi.org/10.1016/j.enconman.2016.07.007

WALL, G., (1990), "Exergy Conversion In The Japanese Society," Energy ,15, 435-444.

https://doi.org/10.1016/0360-5442(90)90040-9

Wall, G., (2003), "Exergy tools," J. Power and Energy ,217, 125-137. https://doi.org/10.1243\%2F09576500360611399

Yazdanifard, F., Ebrahimnia-Bajestan, E., and Ameri, M., (2017). "Performance of a parabolic trough concentrating photovoltaic/thermal system: Effects of flow regime, design parameters, and using nanofluids," Energy Conversion and Management ,148, 1265-1277. https://doi.org/10.1016/j.enconman.2017.06.075

Yimin Xuana, W. R., (2000), "Conceptions for heat transfer correlation of nanofluids," International Journal of Heat and Mass Transfer ,43, 3701-3707.

https://doi.org/10.1016/S0017-9310(99)00369-5

Zhao, N., Guo, L., Qi, C., Chen, T., and Cui, X., (2019), "Experimental analysis on thermo-hydraulic performance of nanofluids in CPU heat sink with rectangular grooves and cylindrical bugles based on exergy efficiency," Energy Conversion and Management ,181, 235-246. https://doi.org/10.1016/j.enconman.2018.11.076 